\title{
7T Epilepsy Task Force Consensus Recommendations on the Use of 7T MRI in Clinical Practice
}

Citation for published version (APA):

Opheim, G., van der Kolk, A., Bloch, K. M., Colon, A. J., Davis, K. A., Henry, T. R., Jansen, J. F. A., Jones, S. E., Pan, J. W., Rossler, K., Stein, J. M., Strandberg, M. C., Trattnig, S., de Moortele, P. F. V., Vargas, M. I., Wang, I., Bartolomei, F., Bernasconi, N., Bernasconi, A., ... Guye, M. (2021). 7T Epilepsy Task Force Consensus Recommendations on the Use of 7T MRI in Clinical Practice. Neurology, 96(7), 327-341. https://doi.org/10.1212/WNL.0000000000011413

Document status and date:

Published: 16/02/2021

DOI:

10.1212/WNL.0000000000011413

Document Version:

Publisher's PDF, also known as Version of record

Document license:

Taverne

Please check the document version of this publication:

- A submitted manuscript is the version of the article upon submission and before peer-review. There can be important differences between the submitted version and the official published version of record.

People interested in the research are advised to contact the author for the final version of the publication, or visit the DOI to the publisher's website.

- The final author version and the galley proof are versions of the publication after peer review.

- The final published version features the final layout of the paper including the volume, issue and page numbers.

Link to publication

\footnotetext{
General rights Owners
rights.

- You may freely distribute the URL identifying the publication in the public portal. please follow below link for the End User Agreement:

www.umlib.nl/taverne-license

Take down policy

If you believe that this document breaches copyright please contact us at:

repository@maastrichtuniversity.nl

providing details and we will investigate your claim.
}

Copyright and moral rights for the publications made accessible in the public portal are retained by the authors and/or other copyright owners and it is a condition of accessing publications that users recognise and abide by the legal requirements associated with these

- Users may download and print one copy of any publication from the public portal for the purpose of private study or research.

- You may not further distribute the material or use it for any profit-making activity or commercial gain

If the publication is distributed under the terms of Article $25 \mathrm{fa}$ of the Dutch Copyright Act, indicated by the "Taverne" license above, 


\section{T Epilepsy Task Force Consensus Recommendations on the Use of 7T MRI in Clinical Practice}

Giske Opheim, MSc, Anja van der Kolk, MD, PhD, Karin Markenroth Bloch, PhD, Albert J. Colon, MD, PhD, Kathryn A. Davis, MD, MS, Thomas R. Henry, MD, Jacobus F.A. Jansen, PhD, Stephen E. Jones, MD, PhD, Jullie W. Pan, PhD, Karl Rössler, MD, DMSc, Joel M. Stein, MD, PhD, Maria C. Strandberg, MD, PhD, Siegfried Trattnig, MD, DMSc, Pierre-Francois Van de Moortele, PhD, Maria Isabel Vargas, MD, Irene Wang, PhD, Fabrice Bartolomei, MD, PhD, Neda Bernasconi, MD, PhD, Andrea Bernasconi, MD, Boris Bernhardt, PhD, Isabella Björkman-Burtscher, MD, PhD, Mirco Cosottini, MD, PhD,

Sandhitsu R. Das, PhD, Lucie Hertz-Pannier, MD, PhD, Sara Inati, MD, Michael T. Jurkiewicz, MD, PhD, Ali R. Khan, PhD, Shuli Liang, MD, PhD, Ruoyun Emily Ma, PhD, Srinivasan Mukundan, MD, PhD, Heath Pardoe, PhD, Lars H. Pinborg, MD, DMSc, Jonathan R. Polimeni, PhD, Jean-Philippe Ranjeva, MD, PhD, Esther Steijvers, BSc, Steven Stufflebeam, MD, PhD, Tim J. Veersema, MD, Alexandre Vignaud, MD, PhD, Natalie Voets, PhD, Serge Vulliemoz, MD, PhD, Christopher J. Wiggins, PhD, Rong Xue, PhD,

Renzo Guerrini, MD, FRCP, and Maxime Guye, MD, PhD

Neurology ${ }^{\circledR}$ 2021;96:327-341. doi:10.1212/WNL.0000000000011413

\author{
Correspondence \\ Giske Opheim \\ giskeopheim@nru.dk
}

\section{Abstract}

Identifying a structural brain lesion on MRI has important implications in epilepsy and is the most important factor that correlates with seizure freedom after surgery in patients with drug-resistant focal onset epilepsy. However, at conventional magnetic field strengths (1.5 and 3T), only approximately $60 \%-85 \%$ of MRI examinations reveal such lesions. Over the last decade, studies have demonstrated the added value of 7T MRI in patients with and without known epileptogenic lesions from 1.5 and/or 3T. However, translation of 7T MRI to clinical practice is still challenging, particularly in centers new to $7 \mathrm{~T}$, and there is a need for practical recommendations on targeted use of 7T MRI in the clinical management of patients with epilepsy. The 7T Epilepsy Task Force-an international group representing $217 \mathrm{~T}$ MRI centers with experience from scanning over 2,000 patients with epilepsy - would hereby like to share its experience with the neurology community regarding the appropriate clinical indications, patient selection and preparation, acquisition protocols and setup, technical challenges, and radiologic guidelines for 7T MRI in patients with epilepsy. This article mainly addresses structural imaging; in addition, it presents multiple nonstructural MRI techniques that benefit from $7 \mathrm{~T}$ and hold promise as future directions in epilepsy. Answering to the increased availability of 7T MRI as an approved tool for diagnostic purposes, this article aims to provide guidance on clinical 7T MRI epilepsy management by giving recommendations on referral, suitable 7T MRI protocols, and image interpretation.

From the Neurobiology Research Unit (G.O., L.H.P.), and Epilepsy Clinic (L.H.P.), Department of Neurology, Rigshospitalet Copenhagen University Hospital; Faculty of Health and Medical Sciences (G.O.), UCPH, Denmark; Departments of Neurology and Neurosurgery (T.J.V.), UMC Utrecht Brain Center, and Department of Radiology (A.v.d.K.), University Medical Center Utrecht Utrecht University; Department of Radiology (A.v.d.K.), Netherlands Cancer Institute Antoni van Leeuwenhoek Hospital, Amsterdam; Lund University Bioimaging Center (K.M.B.), Lund University, Sweden; Department of Neurology (A.J.C.), Neurophysiology and Neurosurgery, ACE Kempenhaeghe/MUMC, Heeze/Maastricht, the Netherlands; Department of Radiology (.M.S.) and Penn Epilepsy Center (K.D.), Hospital of the University of Pennsylvania, Philadelphia; Department of Neurology (T.R.H.) and Center for Magnetic Resonance Research (P.-F.V.d.M., R.E.M.), University of Minnesota, Minneapolis; Department of Radiology and Nuclear Medicine (J.F.A.J.), Maastricht University Medical Center; School for Mental Health and Neuroscience (J.F.A.J.), Maastricht University; Department of Electrical Engineering (J.F.A.J.), Eindhoven University of Technology, the Netherlands; Imaging Institute (S.E.J.) and Epilepsy Center (I.W.), Cleveland Clinic, $\mathrm{OH}$; Department of Neurology and Radiology (J.W.P.), University of Pittsburg, PA; Department of Neurosurgery (K.R.), Medical University of Vienna, Austria; Departments of Neurology and Clinical Sciences (M.C.S.), Lund University Hospital, Sweden; Department of Biomedical Imaging and Image Guided Therapy (S.T.), High Field MR Center, Medical University of Vienna, Austria; Neuroradiology Division, Diagnostic Unit (M.I.V.), University Hospitals and Faculty of Medicine of Geneva, Switzerland; Epileptology Department - INS (F.B.) and CRMBM - CEMEREM (J.-P.R., M.G.), Timone Hospital APHM, Aix Marseille Univ, INSERM, CNRS, France; Neuroimaging of Epilepsy Laboratory (NOEL) (N.B., A.B.), Montreal Neurological Institute (B.B.), and McConnell Brain Imaging Centre (N.B., A.B.), McGill University, Montreal, Canada; Department of Radiology (I.B.-B.), Institute of Clinical Sciences, Sahlgrenska Academy, University of Gothenburg, Sweden; Department of Translational Research and New Technologies in Medicine and Surgery (M.C.), University of Pisa, Italy; Department of Neurology (S.R.D.), University of Pennsylvania, Philadelphia; NeuroSpin (L.H.-P., A.V.), Paris-Saclay University, CEA, CNRS, BAOBAB, Gif-sur-Yvette, France; UMR 1141 (L.H.-P), University of Paris, France; EEG Section (S.I.), NINDS, NIH, Bethesda, MD; Department of Medical Imaging (M.T.J.), Children's Hospital at London Health Sciences Centre; Department of Medical Biophysics (M.T.J., A.R.K.), Schulich School of Medicine and Dentistry, The University of Western Ontario, London, Canada; Imaging Research Laboratories (A.R.K.), Robarts Research Institute, London, ON, Canada; Functional Neurosurgery Department (S.L.), Beijing Children's Hospital of Capital Medical University, Beijing, China; Department of Radiology (S.M.), Brigham and Women's Hospital, Harvard Medical School, Boston, MA; NYU Grossman School of Medicine (H.P.), New York; Harvard MIT Division of Health Sciences and Technology (J.R.P., S.S.), Massachusetts Institute of Technology, Cambridge; Athinoula A. Martinos Center for Biomedical Imaging (I.R.P., S.S.), Department of Radiology, Harvard Medical School, Massachusetts General Hospital, Charlestown, MA; Scannexus Ultrahigh Field MRI Research Center (E.S., C.J.W.), Maastricht; Department of Radiology and Nuclear Medicine (T.J.V.), Meander Medical Center, Amersfoort, the Netherlands; Wellcome Centre for Integrative Neuroimaging (N.V.), FMRIB Division, Nuffield Department of Clinical Neurosciences, University of Oxford, United Kingdom; EEG and Epilepsy Unit (S.V.), Neurology, Department of Clinical Neurosciences, University Hospitals and Faculty of Medicine of Geneva, Switzerland; State Key Lab of Brain and Cognitive Science (R.X.), Beijing MRI Center for Brain Research, Institute of Biophysics, Chinese Academy of Sciences, China; Neuroscience Department (R.G.), Children's Hospital A. Meyer-University of Florence; and IMAGO 7 Foundation (R.G.), Florence, Italy

Go to Neurology.org/N for full disclosures. Funding information and disclosures deemed relevant by the authors, if any, are provided at the end of the article. 


\section{Glossary}

DNET $=$ dysembryoplastic neuroepithelial tumor; DRFE = drug-resistant focal epilepsy; FCD = focal cortical dysplasia; FLAIR = fluid-attenuated inversion recovery; FWMS = fluid and white matter suppressed; GRE = gradient-recalled echo; HS = hippocampal sclerosis; LEAT = long-term epilepsy-associated tumor; $\mathbf{M C D}=$ malformations of cortical development; MPRAGE = magnetization-prepared rapid acquisition gradient echo; MRS = magnetic resonance spectroscopy; RF = radiofrequency; SNR = signal-to-noise ratio; SWAN = susceptibility-weighted angiography; SWI = susceptibility-weighted imaging; TLE = temporal lobe epilepsy; TSE = turbo spin echo; UHF = ultrahigh field.

Epilepsy is drug resistant in approximately $30 \%-40 \%$ of patients. ${ }^{1}$ In drug-resistant focal epilepsy (DRFE), surgical resection, laser ablation, and disconnection of the epileptogenic zone or network are the only curative options. The chances of successful postsurgical outcome are 2.5-3 times higher if an epileptogenic lesion is identified by MRI. ${ }^{2}$ However, precise identification of the resection margin, which is essential for optimizing surgical outcomes, is often difficult using 1.5 or 3T. Moreover, the absence of an MRI-detectable lesion in approximately one-third of patients with DRFE is a major limitation to surgical candidacy. Finally, normal-appearing MRI also hampers targeting for intracranial electrode implantation, which, in addition to seizure onset localization, is also used for chronic brain electrostimulation therapies and targeted laser ablation.

7T MRI, compared with lower field strengths, has increased signal-to-noise ratio (SNR) and susceptibility effects, thereby providing better image contrast, higher spatial resolution, and stronger susceptibility contrast. ${ }^{3,4}$ These advantages offered by $7 \mathrm{~T}$ may address multiple preoperative and postoperative problems in DRFE, including lesion detection (especially malformations of cortical development [MCD]) in 16\%-32\% of previously MRI-negative patients, and identification of residual epileptogenic tissue after surgical failures. ${ }^{5-10}$ Notwithstanding these advantages, technical challenges such as inhomogeneous radiofrequency (RF) distributions present limitations on ultrahigh field systems and add certain challenges for its use in epilepsy. An excellent review article on scientific developments of 7T in epilepsy has recently been published. ${ }^{11}$ The present study provides guidance for setting up a $7 \mathrm{~T}$ epilepsy protocol for clinical use, based on the collective experience of 21 centers in which over 2000 7T MRI epilepsy examinations were performed.

\section{Clinical Indications, Patient Preparation, and Safety}

When operating a non-CE/FDA-approved 7T MRI scanner, clinical patient scanning should be authorized by the local institutional review board (IRB), considering both clinical benefits and possible safety issues.

When planning clinical 7T MRI for an individual with epilepsy, one should pay attention to patient-specific indications for additional enhanced brain imaging, any contraindications to MRI in general and 7T in particular, and other potential issues inherent to the ultrahigh field (UHF) environment. Thorough evaluation of these 3 factors improves the diagnostic gain of 7T MRI by making optimal use of its advantages - and adapting to its limitations. Given the currently limited availability of clinical 7T MRI platforms, most centers focus on indications for the referral of patients with DRFE for 7T MRI, as opposed to general diagnostic purposes.

\section{Clinical Indications}

The main indications for 7T MRI in epilepsy are to improve imaging to identify a possible morphological lesion responsible for DRFE and to better delineate or classify known lesions. We have identified 4 main indications based on a priori knowledge at the time of 7T MRI referral.

\section{T MRI-Negative Cases}

The objective is to detect possible lesions missed by the currently recommended epilepsy-specific $3 \mathrm{~T}$ MRI protocol. ${ }^{12,13}$ The presence of so far undetected lesions can be supported by the clinical history, ictal semiology, interictal and especially ictal scalp EEG, PET, or SPECT.

\section{Lesion Typing, Delineation, and False Positives}

Related to the evaluation of known/suspected lesions, this main indication covers further characterization of known structural abnormalities deemed suitable for resection by improved profiling of the abnormality, including distinction of neoplastic lesions, optimal delineation of MCD and scarring lesions, and distinguishing pathologic lesions from benign or unknown morphological variants. This analysis also includes resolving false-positive 3T MRI (in Radiologic Considerations and Visual Assessment), which may lead to misguided clinical management without the added information from $7 \mathrm{~T}$ MRI.

\section{Electrode Positioning}

Improved lesion characterization and visualization of adjacent structures may also augment planning of intracranial electrode positioning for electrophysiologic measurements or electrostimulation therapy. This is facilitated by the increased anatomic details at 7T that enable consideration of fine structures with subtle signal changes, atrophy, or malformations. However, potential increased geometric distortion in some sequences due to stronger magnetic field must be considered.

\section{Eloquent Areas}

Iatrogenic injury to sites of normal cerebral physiology may be avoided by interictal mapping using stimulation or resting- 
Table 1 Summary of the 8 Most Useful Sequences as Identified in a Survey From 19 7T MRI Centers Experienced in Examining Patients With Epilepsy For Research and/or Diagnostic Purposes

\begin{tabular}{|c|c|c|c|c|}
\hline Sequence type & Orientation & $\begin{array}{l}\text { In-plane spatial resolution in } \mathrm{mm} \text {, range } \\
\text { (median) }\end{array}$ & $\begin{array}{l}\text { Slice thickness in } \mathrm{mm} \text {, range } \\
\text { (median) }\end{array}$ & $\begin{array}{l}\text { Duration in mm:ss, range } \\
\text { (median) }\end{array}$ \\
\hline \multicolumn{5}{|c|}{ Limited coverage } \\
\hline \multicolumn{5}{|l|}{$T_{2} W^{a}$} \\
\hline $\mathrm{TSE}^{1}$ & Coronal & $0.25-0.70(0.30)$ & $1.00-3.00(1.35)$ & $3: 36-8: 48$ (5:58) \\
\hline $\mathrm{TSE}^{8}$ & Axial & $0.40-0.70(0.45)$ & $0.75-3.00(1.55)$ & $3: 39-12: 00(6: 17)$ \\
\hline \multicolumn{5}{|l|}{$\mathrm{T}_{2}{ }^{*} \mathrm{w}^{6}$} \\
\hline GRE & Coronal & $0.25-0.38(0.30)$ & $1.65-2.00(2.00)$ & $5: 22-6: 12(5: 58)$ \\
\hline \multicolumn{5}{|l|}{$\begin{array}{l}\text { Whole-brain } \\
\text { coverage }\end{array}$} \\
\hline \multicolumn{5}{|l|}{ 3D $T_{1} w$} \\
\hline MPRAGE $^{4}$ & Sagittal & $0.60-0.90(0.73)$ & $0.60-1.00(0.73)$ & $6: 47-10: 12(8: 27)$ \\
\hline MP2RAGE $^{2}$ & Sagittal & $0.60-0.80(0.70)$ & $0.60-0.80(0.70)$ & $5: 20-11: 45(6: 21)$ \\
\hline 3D FLAIR ${ }^{3}$ & Sagittal & $0.70-1.00(0.80)$ & $0.70-1.40(0.80)$ & $5: 54-10.38(7: 27)$ \\
\hline \multicolumn{5}{|l|}{$3 D T_{2}{ }^{*} w^{7}$} \\
\hline GRE/SWI & Any & $0.25-0.80(0.50)$ & $0.20-2.00(0.90)$ & $5: 17-12: 00(8.27)$ \\
\hline \multicolumn{5}{|l|}{$3 D T_{2} w^{5}$} \\
\hline TSE & $\begin{array}{l}\text { Sagittal/ } \\
\text { axial }\end{array}$ & $0.50-0.80(0.70)$ & $0.69-2.40(0.70)$ & $5: 32-10: 59(7: 11)$ \\
\hline
\end{tabular}

Abbreviations: FLAIR = fluid-attenuated inversion recovery; GRE = gradient-recalled echo; MPRAGE = magnetization-prepared rapid acquisition gradient echo; SWI = susceptibility-weighted imaging; TSE = turbo spin echo; $w=$ weighted.

a In a few centers, the multislice $\mathrm{T}_{2}$-weighted TSE sequences were reconstructed to an even higher spatial resolution. ${ }^{1-8}$ The order of importance as scored by the involved radiologists.

state fMRI. The greater BOLD SNR performance of 7T MRI offers considerable advantages in mapping eloquent cortex over $1.5 \mathrm{~T}$ and $3 \mathrm{~T}$ fMRI. ${ }^{12,14}$

\section{Tolerability Issues at 7T}

Although patient motion can be detrimental for image assessment at any field strength, this effect is even more pronounced at 7T. The most efficient way to minimize motion is to prepare patients before the MRI examination. However, even patients who have previously undergone MRI examinations can encounter specific issues or physical sensations at $7 \mathrm{~T}$ that we recommend addressing during preparation. ${ }^{13}$

\section{Longer Acquisition Times}

To make optimal use of the advantages of UHF MRI, individual 7T sequences (table 1) - and therefore whole MRI protocols - will often take longer to acquire than at 3T. Lying supine inside the MRI scanner for such long times may cause discomfort and musculoskeletal pain in a subset of patients (approximately $25 \%) .{ }^{15}$ Sleepiness is also more likely to occur and might increase the risk of seizures in some patients with DRFE.

\section{Longer Scanner Bore and Smaller Head Coil}

The longer scanner bore may induce claustrophobia. In addition, the most commonly used head coil is smaller than at lower field strengths; patients with larger heads will therefore receive a thinner pillow under the head, which often leads to numbness in the back of the head (Task Force experience; $\sim 40 \%$ feels discomfort during the examination). ${ }^{15,16}$ Another consequence of smaller head coils is the lack of space for headphones, which is why most centers use earplugs and/or a soft clay to compensate for the loud noises unavoidable in any MRI scanner.

\section{Peripheral Nerve Stimulation (PNS)}

Some patients have reported mild discomfort or anxiety due to PNS, which can present as tingling or twitches in upper limbs or large muscle groups. Most clinical sequences are designed to have limited PNS. However, sensitivity to these physical sensations differs between patients; reported prevalence varies widely from $23 \%$ to $63 \% .{ }^{15-17}$

\section{Dizziness}

Dizziness caused by movement in and out of the $B_{0}$ field is one of the most frequently reported sensations $(25 \%-80 \%) \cdot{ }^{15-17}$ To suppress this issue, very slow movement of the patient table into the scanner-which may be preconfigured by vendors-is recommended. Usually, dizziness will pass shortly (30-60 seconds) after positioning. During this movement, patients may also sense a metallic taste. 
Table 2 Summary of Sequences of Particular Interest For Certain (Known and/or Suspected) Epileptic Lesion Types; Often Used Acquisition Parameters Can Be Found in the Text and in table 1

\begin{tabular}{|c|c|}
\hline Lesion type & Sequences of particular interest \\
\hline \multirow{3}{*}{$\begin{array}{l}\text { Temporal lobe epilepsy with } \\
\text { known or suspected HS }\end{array}$} & $3 \mathrm{D} \mathrm{T}_{1} \mathrm{~W}$ MPRAGE or MP2RAGE \\
\hline & $3 \mathrm{D} \mathrm{T}_{2} \mathrm{~W}$ TSE \\
\hline & $\begin{array}{l}2 \mathrm{D} \mathrm{T}_{2} \mathrm{~W} \text { TSE focused on the } \\
\text { hippocampus and anterior temporal } \\
\text { lobe }\end{array}$ \\
\hline \multirow[t]{5}{*}{$\begin{array}{l}\text { Focal cortical dysplasia (type I } \\
\text { and II) }\end{array}$} & $\begin{array}{l}\text { 3D } T_{1} w \text { MPRAGE or MP2RAGE (whole- } \\
\text { brain) }\end{array}$ \\
\hline & 3D FLAIR \\
\hline & $3 \mathrm{D} \mathrm{T}{ }^{*}{ }^{*} \mathrm{~W}$ GRE or SWI \\
\hline & +/- FWMS sequence \\
\hline & $\begin{array}{l}+/-2 \mathrm{D} \mathrm{T}_{2} \mathrm{~W} \text { TSE focused on the } \\
\text { suspected cortical lesion }\end{array}$ \\
\hline \multirow[t]{3}{*}{ LEAT (gangliogliomas, DNET) } & $3 \mathrm{D} \mathrm{T}_{1} \mathrm{w}$ MPRAGE or MP2RAGE \\
\hline & $3 \mathrm{D} \mathrm{T}_{2} \mathrm{~W}$ TSE \\
\hline & $3 \mathrm{D} \mathrm{T}{ }_{2}{ }^{*} \mathrm{~W}$ (GRE or SWI) \\
\hline \multirow[t]{3}{*}{ Polymicrogyria } & $3 D T_{1} w$ MPRAGE or MP2RAGE \\
\hline & $3 \mathrm{D} \mathrm{T}_{2}{ }^{*} \mathrm{~W}$ (SWI or SWAN) \\
\hline & $+/-$ FSPGR \\
\hline \multirow[t]{3}{*}{ Tuberous sclerosis complex } & $3 \mathrm{D} \mathrm{T}_{1} \mathrm{~W}$ MPRAGE or MP2RAGE \\
\hline & $3 \mathrm{D} \mathrm{T}_{2}{ }^{*} \mathrm{~W}$ (SWI or SWAN) \\
\hline & 3D FLAIR \\
\hline Vascular malformations & $3 \mathrm{D} \mathrm{T}_{2}{ }^{*} \mathrm{~W}(\mathrm{SWI})$ \\
\hline \multirow[t]{6}{*}{ MRI negative at $3 \mathrm{~T}$} & $3 D T_{1} w$ MPRAGE or MP2RAGE \\
\hline & 3D FLAIR \\
\hline & $3 D T_{2} W$ TSE \\
\hline & $3 \mathrm{D} \mathrm{T}_{2}{ }^{*} \mathrm{~W}(\mathrm{GRE}$ or SWI) \\
\hline & +/- FWMS sequence \\
\hline & $\begin{array}{l}+/-2 \mathrm{DT}_{2} \mathrm{~W} \text { TSE over regions indicated } \\
\text { by, e.g., EEG }\end{array}$ \\
\hline \multicolumn{2}{|c|}{$\begin{array}{l}\text { Abbreviations: DNET = dysembryoplastic neuroepithelial tumor; FLAIR = fluid- } \\
\text { attenuated inversion recovery; FSPGR = fast spoiled gradient echo; FWMS = } \\
\text { fluid and white matter suppressed; GRE = gradient-recalled echo; HS = hip- } \\
\text { pocampal sclerosis; LEAT = long-term epilepsy-associated tumor; MPRAGE = } \\
\text { magnetization-prepared rapid acquisition gradient echo; SWAN = suscepti- } \\
\text { bility-weighted angiography; SWl = susceptibility-weighted imaging; TSE = } \\
\text { turbo spin echo; w = weighted. }\end{array}$} \\
\hline
\end{tabular}

\section{Patient Safety at 7T}

Once the clinical indication for 7T imaging has been established, it should be followed by a critical evaluation of possible contraindications. In this regard, it is important to realize that implants that are MR compatible at $3 \mathrm{~T}$ may be incompatible at $7 \mathrm{~T}$, presenting a serious safety hazard. We therefore recommend thorough safety screening with particular emphasis on potentially hazardous factors that were approved at $3 \mathrm{~T}$ and might be overlooked on referral to $7 \mathrm{~T}$.

There is no whole-body RF coil in a 7T scanner; brain imaging is obtained with the combined transmit/receive coil, which limits the RF field to the head (plus a safety margin). Generally, for implants, displacement force and torque due to $B_{0}$ are higher, and for both implants and tattoos, the risk of $\mathrm{RF}$ heating is increased because of the shorter RF wavelength. Despite initiatives on harmonizing approaches, ${ }^{18}$ there is no global consensus regarding implant safety at $7 \mathrm{~T}$ yet, and centers differ in their approach to contraindications. Some centers have dedicated safety committees that have scanned phantoms and/or obtained electromagnetic field numerical simulations to assess safety margins of common implants and might therefore practice less conservative safety margins relative to the head coil. Until official 7T MRI safety guidelines that cover both implant types and safety margins are in place, implants within the RF coil volume should be locally approved at $7 \mathrm{~T}$ based on literature or local testing. ${ }^{18}$ Further statements regarding these and other safety aspects at $7 \mathrm{~T}$ would in the near future complement already existing recommendations. ${ }^{19}$

\section{Acquisition Protocol and Recommended Setup}

Among other topics, the survey answered by centers in our Task Force contained questions on which sequences they use in patients with epilepsy and to what degree they are useful for radiologic evaluation. When comparing protocols, the majority included a subset of structural sequences, which although differed in parameter settings served the same purpose. The contrast weightings in the protocols mirrored those included in the most recent recommendations for 3T MRI of patients with epilepsy, ${ }^{12}$ taking advantage of the increased magnetic field mainly by increasing spatial resolution. Based on frequency of use and radiologic rating of importance, 8 sequences across 4 different contrast weightings scored highest and were presented to the Task Force for consensus voting. These 8 sequences will be discussed in detail in the following paragraphs, whereas major acquisition parameters can be found in table 1 . Specific sequence recommendations based on clinical indication are given in table 2; a general protocol takes approximately 50 minutes to acquire.

\section{Most Valued Sequences in (Clinical) Practice}

\section{D $\mathrm{T}_{1}$-Weighted Sequences}

Because of the significantly longer acquisition times of spin echo-based sequences, gradient echo (GRE)-based MPRAGE ${ }^{20}$ or MP2RAGE ${ }^{21,22}$ is the mainstay for $\mathrm{T}_{1}$-weighted imaging at $7 \mathrm{~T}$, with isotropic voxel sizes ranging from 0.6 to $0.9 \mathrm{~mm}$. The main advantage of using MP2RAGE over MPRAGE is its better resistance to RF field inhomogeneity; MP2RAGE can therefore 

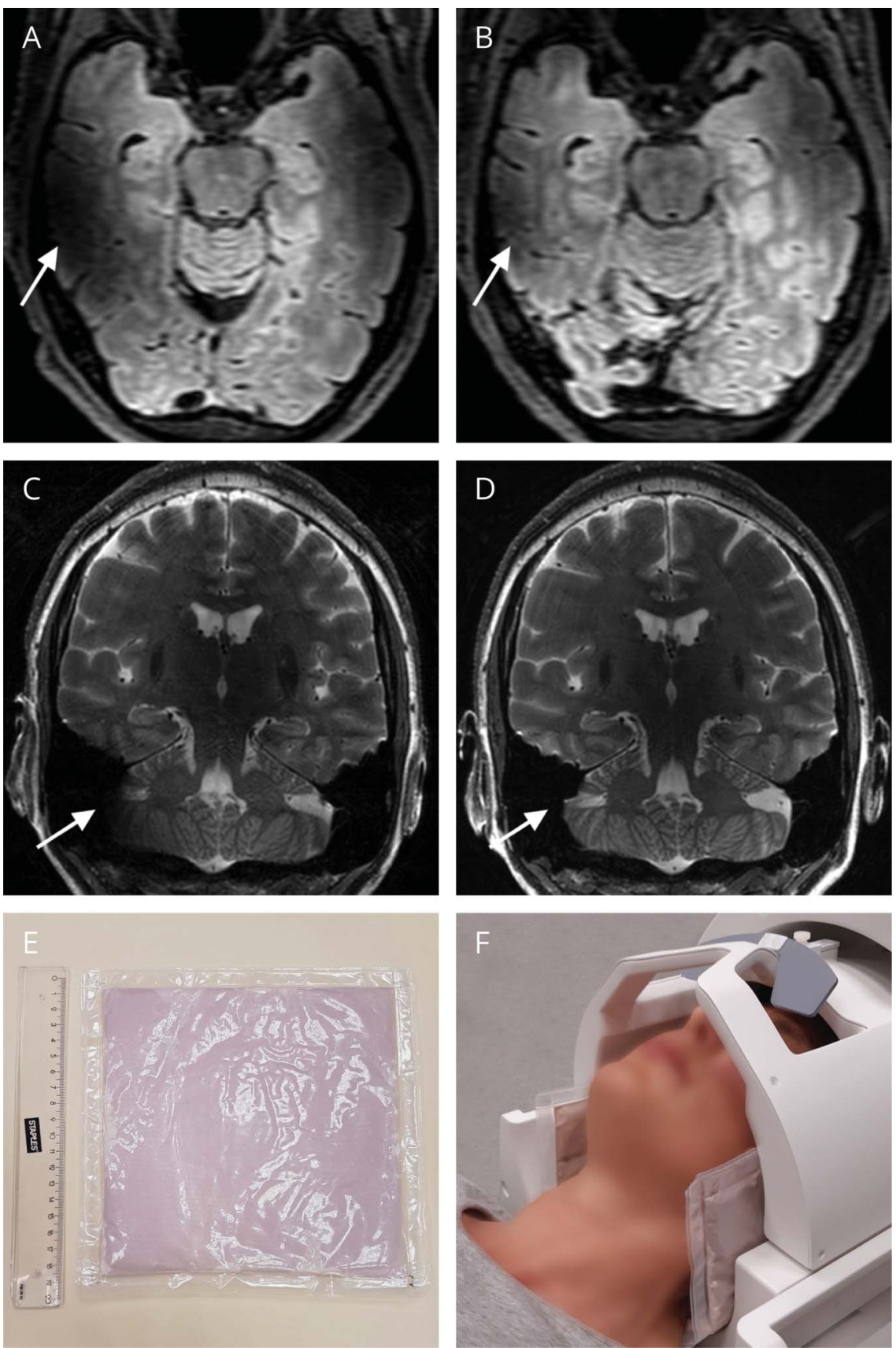

Illustration of the effect of dielectric pads on (A and $B$ ) 3D fluid-attenuated inversion recovery (FLAIR, $0.7 \mathrm{~mm}$ isotropic resolution) and ( $\mathrm{C}$ and D) $T_{2}$-weighted sequences $(0.3 \times 0.3 \times 1.5 \mathrm{~mm}$ resolution). In ( $A$ and $C)$, no pads are used, whereas in (B and $D)$ they are. Arrows indicate corresponding areas before and after signal improvement (A versus B, C versus D). The dielectric pads used in this case are $19 \times 19 \mathrm{~cm}(\mathrm{E})$; pad placement for obtaining images ( $B$ and $D$ ) is demonstrated in image (F). Of note, optimal pad placement depends on the head size and shape. also be useful in quantitative techniques. However, some 7T platforms are not equipped with an embedded pipeline to process MP2RAGE data and output DICOM images, in which case offline processing is required, which hampers clinical workflow with PACS export.

\section{D Fluid Attenuation Inversion Recovery (FLAIR) Sequence}

A 3D FLAIR with isotropic reconstructed spatial resolutions of $0.7-0.8 \mathrm{~mm}$ and whole-brain coverage is preferred because it can be reformatted in any orientation. Implementation of FLAIR at
$7 \mathrm{~T}$ is not trivial for several reasons. ${ }^{23}$ From a technical point of view, RF-pulses at $7 \mathrm{~T}$ have to be insensitive to the inhomogeneities of the $\mathrm{B}_{0}$ and $\mathrm{RF}$ field over the brain, while also complying with the restrictions on specific absorption rate (SAR). 3D FLAIR sequences are very sensitive to flip angle (FA) calibrations; if the true FA deviates too much from the set FAwhich is spatially different at $7 \mathrm{~T}$ because of RF field inhomogeneity-signal dropouts will occur and may hamper image assessment. As a consequence, finding the balance between signal intensities across the brain may be subject to radiologic priorities, that is, whether a radiologist wants to focus on medial 

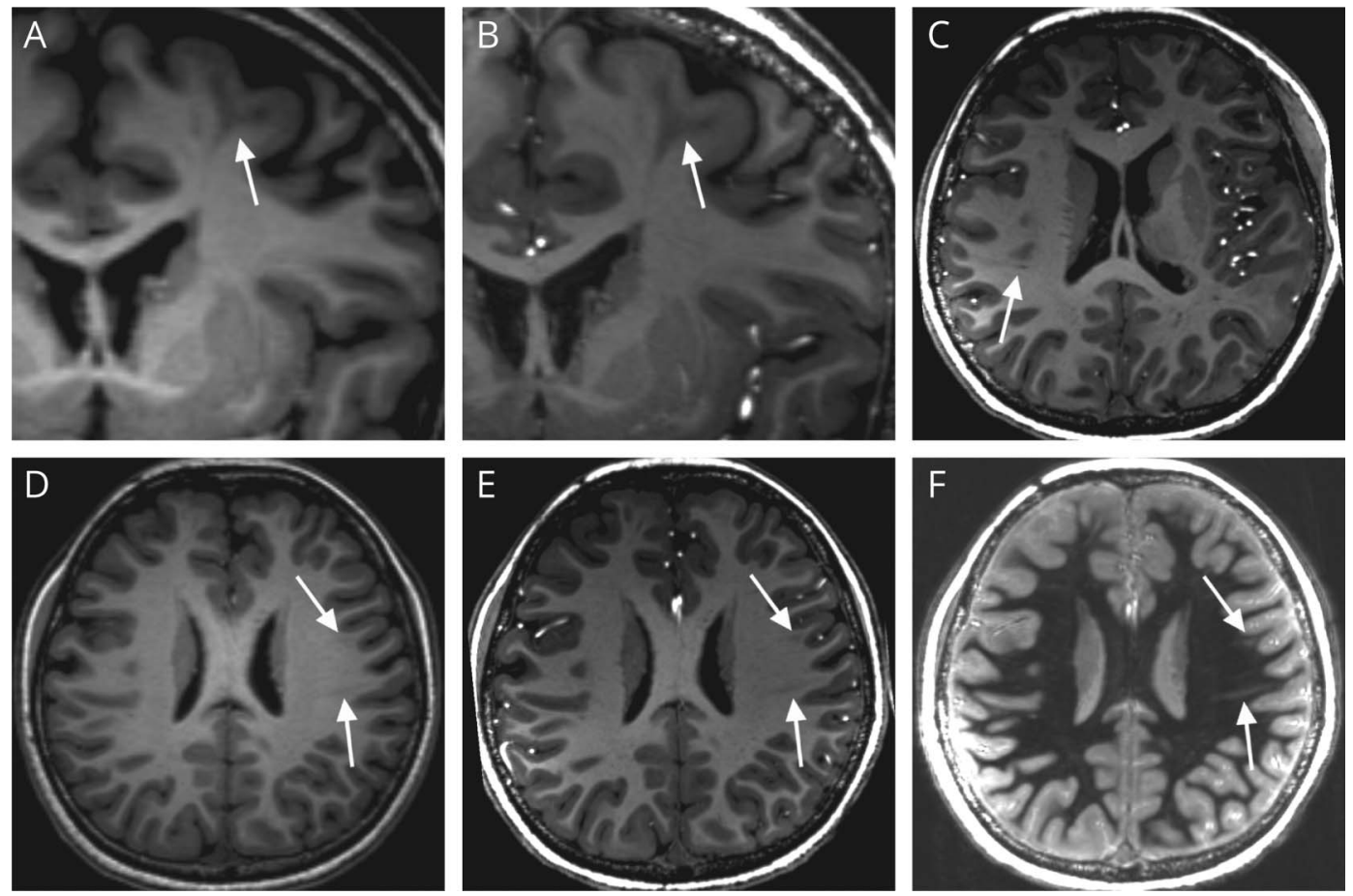

3T $\mathrm{T}_{1}$-weighted $0.9 \mathrm{~mm}$ isotropic MPRAGE (A and $\mathrm{D}$ ), $7 \mathrm{~T} \mathrm{~T}_{1}$-weighted $0.6 \mathrm{~mm}$ isotropic MPRAGE (B-D), and $0.8 \mathrm{~mm}$ isotropic white matter-suppressed $\mathrm{T}_{1}$-weighted images (F) in an 11-year-old girl diagnosed with tuberous sclerosis complex (TSC). Cortical tubers were found throughout the brain both at 3T and 7T MRI (arrow in A and B). Radial migration bands, however, were much more difficult to visualize; subtle radial bands could be identified at 7T in the left frontal and parietal lobe (arrows in E and F), which were only retrospectively seen at $3 \mathrm{~T}$ (D). In addition, more detailed structures surrounding both tubers and radial bands, as well as previously unidentified subtle TSC abnormalities such as a small cyst associated with a radial band in the right parietal lobe (C), were seen only at 7T images. This detailed delineation of TSC abnormalities may improve surgical resection, thereby increasing the likelihood of a seizure-free postoperative outcome. Courtesy of Kaibao Sun, PhD, Center for MR Research, University of Illinois at Chicago, Chicago, IL, USA. Data were acquired during his employment at the State Key Lab. of Brain and Cognitive Science, Beijing MRI Center for Brain Research, Institute of Biophysics, Chinese Academy of Sciences, Beijing, China.

(prioritize low FA) or lateral (prioritize high FA) structures. These difficulties have led to research into new types of RF pulse strategies and sequence designs $s^{24,25}$ to mitigate these problems.

\section{$\mathrm{T}_{2}$-Weighted Sequences}

The obtainable in-plane spatial resolution of $\mathrm{T}_{2}$-weighted sequences depends on the requested coverage and is limited by SNR, acquisition time, and patient motion. For instance, to cover the hippocampus with a coronal $\mathrm{T}_{2}$-weighted sequence within a reasonable time, in-plane acquisition resolutions of $0.25-0.50 \mathrm{~mm}$ are used, with slice thicknesses of $1-2 \mathrm{~mm}$. However, this will increase sensitivity to patient motion because of the long acquisition times (table 1). These sequences are therefore natural targets for motion correction techniques. The 3D $\mathrm{T}_{2}$-weighted TSE sequence has less obvious motion artifacts than the multislice $\mathrm{T}_{2}$-weighted sequences, however at the expense of a less pronounced image contrast and higher sensitivity to RF field inhomogeneity. For this 3D sequence, an isotropic spatial resolution of $0.5-0.8 \mathrm{~mm}$ and whole-brain coverage is recommended.

\section{$\mathrm{T}_{2}{ }^{*}$-Weighted Sequences}

Because of more pronounced susceptibility effects at $7 \mathrm{~T}$, image contrast in $\mathrm{T}_{2}{ }^{*}$-weighted sequences increases. Many centers use $3 \mathrm{D} \quad \mathrm{T}_{2}{ }^{*}$-weighted sequences (GRE or susceptibility-weighted imaging [SWI]) complementary to other images to assess vascular pathologies and vascularity in given structures. A faster, thus less motion-sensitive, alternative to $3 \mathrm{D}$ sequences, is to choose $2 \mathrm{D} \mathrm{T}_{2}{ }^{*}$-weighted sequences that cover specific regions with the same spatial resolution as $3 \mathrm{D}$ sequences.

\section{Use of Dielectric Pads}

The inhomogeneous RF field often manifests as contrast changes or signal losses in the temporal lobes and cerebellum, an effect that is most pronounced on FLAIR images (figure 1, $\mathrm{A}$ and $\mathrm{B}$ ) but also apparent on $\mathrm{T}_{2}$-weighted images (figure 1, C and D). One straightforward way to increase RF field homogeneity is to apply dielectric pads $(<1 \mathrm{~cm}$ thick $)$ on each side of the head, ${ }^{26}$ which is followed by two-thirds of the centers with sizes varying from $10 \times 10$ $\mathrm{cm}^{2}$ to $19 \times 19 \mathrm{~cm}^{2}$ (figure $1 \mathrm{E}$ ). The pads are placed as shown in figure $1 \mathrm{~F}$. To ensure that the contents are always well mixed and to verify cracks/dryness in the compound, we recommend to gently massage pads before each scan. Renewing the pads annually/biannually prevents suboptimal effects due to degradation of the material over time (depending on the type). Of note, by introducing dielectric pads into the transmit coil, SAR estimations produced by the scanner are no longer valid. It is therefore 

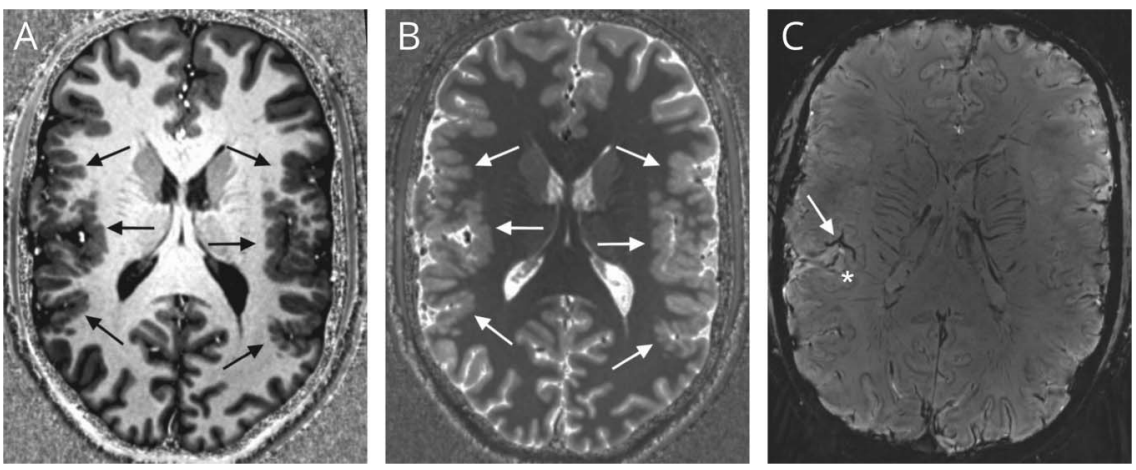

7T $\mathrm{T}_{1}$-weighted MP2RAGE (A) and MP2RAGE $\mathrm{T}_{1}$ map (B) images illustrate thickening of the perisylvian cortex (arrows in A and B) in an 18-yearold patient who had known polymicrogyria as already visualized at $3 T$ MRI; clinical indication for 7T imaging was better lesion delineation. An additional 7T $\mathrm{T}_{2}$ *-weighted (SWI) sequence (C) shows a hyperintense cortex associated with veins perpendicular to the cortex ( $*$ in $C$ ) and a tree-like distribution of vessels (arrow in C).

important that simulations of pad placements are made to ensure patient safety. Such simulations have been made and published for the standard NOVA head coil (1- and 2-channel transmit, NOVA Medical, Wilmington, MA, USA), ${ }^{27}$ which is used in most $7 \mathrm{~T}$ centers worldwide. When using other coils, new simulations should be performed, and the pads should not be used if transmission settings are varied between patients unless on-the-fly SAR calculations including the pads are done.

\section{Deciding on the Imaging Protocol}

The individual patient-specific indications for $7 \mathrm{~T}$ imaging (in Clinical indications) will drive the selection of sequences, which should be performed in the order of priority to preempt motion artifacts from hampering assessment of the most important sequences. Recommendations for a minimum scan protocol can be found in table 2 .

\section{Radiologic Considerations and Visual Assessment}

Moving to 7T requires adaptation of the observer's blueprint of what healthy tissue and pathology looks like. The changes in image quality aspects at 7T can be perceived as an improvement, or sometimes the contrary. For virtually all 7T images, contrast between tissues will be much higher. For instance, the cortex will be more discernible from white matter, basal ganglia will have more heterogeneous signal intensity reflective of substructures that can now be discriminated, and very small vessels, perivascular spaces, and u-fibers are clearly identifiable. Although the amount of perivascular spaces has been suggested to correlate with seizure laterality, ${ }^{28}$ these findings are normal and should not be interpreted as pathology; on the contrary, they can be used for resolving false-positive blurring and transmantle signs at 3T. Another characteristic 7T finding (caused by RF transmit head coils) on T1-weighted (MPRAGE/MP2RAGE) images is that arteries appear bright even without contrast administration.
RF field inhomogeneity effects (in Acquisition protocol and recommended setup) are substantial and remain one of the most significant artifacts at 7T. These effects, however, can be partially suppressed by RF shimming, for example, through the use of dielectric pads (figure 1). Furthermore, susceptibility artifacts will be more pronounced, particularly in areas close to air-containing structures, which may overlap with those affected by RF field inhomogeneities. An additional strategy is to adapt the window width and level, depending on which part of the brain is of interest; this will improve image contrast in, for example, the temporal lobes, whereas the center of the brain will be less assessable with those same settings. Flow artifacts in and from large vessels are also present, and in cases in which such artifacts extend across gray and white matter, care should be taken not to mistake these for pathology. Because there currently does not exist any uniform 7T-specific training material, we recommend surveying several 7T MRI scans, preferably of healthy volunteers, to get acquainted with these characteristics and thus avoid mistaking them for $7 \mathrm{~T}$ false positives in the epilepsy examination routine. The following section provides detailed imaging findings and sequence considerations for selected lesions for which our collective experiences consider 7T MRI particularly helpful.

\section{Malformations of Cortical Development (Excluding Focal Cortical Dysplasia)}

\section{Tuberous Sclerosis Complex (TSC) and Long-Term Epilepsy-Associated Tumors (LEATS: Gangliogliomas and Dysembryoplastic Neuroepithelial Tumors [DNET]) (Barkovich Group I)}

The increased spatial resolution and image contrast at 7T improves detection and delineation of cerebral lesions in TSC such as cortical and subependymal tubers, ${ }^{29}$ cortical dysplasia, and white matter abnormalities. ${ }^{30}$ Also, a new finding first identified at $7 \mathrm{~T}$ is the presence of tortuous veins associated with subependymal tubers. ${ }^{30,31}$ Next to $\mathrm{T}_{2}$-weighted/FLAIR imaging for visualization of cortical tubers and white matter $a b$ normalities, and $3 \mathrm{D} \mathrm{T}_{1}$-weighted (MP2RAGE or MPRAGE) imaging for cortical and subependymal tubers (figure 2), we particularly recommend a 3D SWI or GRE $\mathrm{T}_{2}{ }^{*}$-weighted 

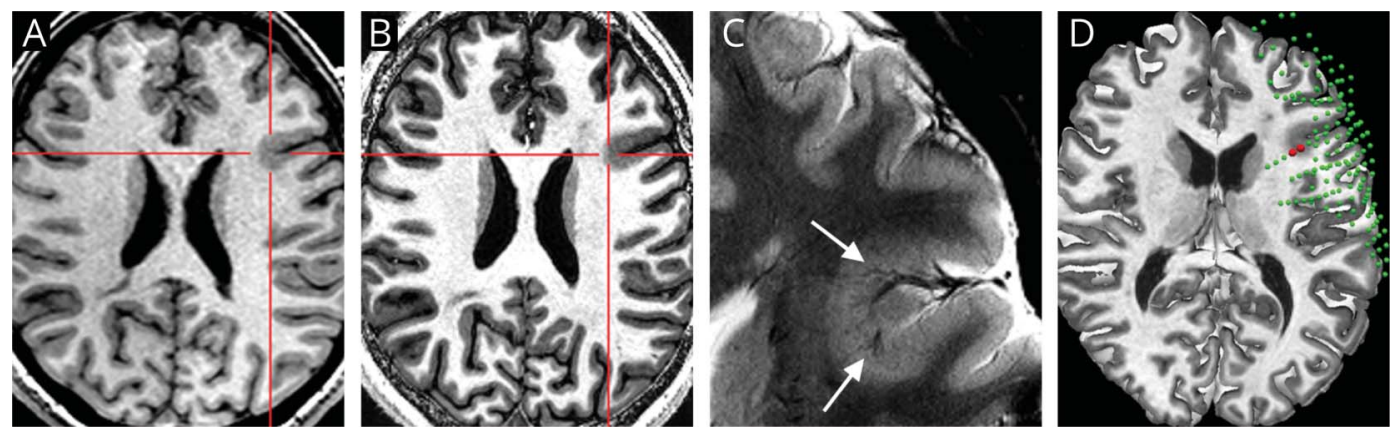

Axial 3T $T_{1}$-weighted MPRAGE (A), axial 7T T $T_{1}$-weighted MP2RAGE (B), and zoomed in axial 7T T ${ }_{2}{ }^{*}$-weighted GRE (C) images of a patient for whom visual review of 7T MRI yielded previously unappreciated subtle findings. The red crosshairs/arrows pinpoint the location of an area of focal cortical dysplasia (FCD), which was detected by visual analysis of 7T images. The vascular changes associated with the FCD can be well appreciated on the $\mathrm{T}_{2}{ }^{*}$-weighted GRE images in panel C (arrows). Detection of this subtle lesion guided subsequent placement of intracranial-EEG (icEEG) with subdural grids and depth electrodes. The icEEG implantation was devised to confirm the epileptogenicity of the subtle lesion and map out the lesion extent and its proximity to eloquent cortex with language function. The subtle lesion location was concordant with ictal onset on the icEEG as shown in the 3D reconstruction of electrode location and 7T MRI, with a 2D axial cut-plane (D). In panel D, green spheres indicate all implanted electrodes and red spheres indicate ictal onset.

sequence because the increased sensitivity to susceptibility effects enables better visualization of (frequently encountered) tuber calcification. Image characteristics at $7 \mathrm{~T}$ are consistent with those seen at lower field strengths; the main advantage is the higher lesion conspicuity leading to both detection of more lesions and better delineation for surgical planning. LEATS (gangliogliomas and DNET) are low-grade tumors that consist of a composition of mature neuronal cells and glial cells. ${ }^{32}$ Imaging characteristics include a solid and/or cystic component, and sometimes edema. At 7T, a 3D $\mathrm{T}_{1}$-weighted (MP2RAGE or MPRAGE) image will better delineate the solid component because of increased image contrast. In addition, $3 \mathrm{D} \mathrm{T}_{2}$-weighted sequences excel at both showing the septa (walls) between and around the solid/cystic components and more precisely delineating the extent of any associated edema. Both factors are important when planning the resection margin for surgical intervention. 3D SWI or GRE $\mathrm{T}_{2}{ }^{*}$-weighted images can additionally evaluate the degree of calcification, which is another common feature of gangliogliomas.

\section{Polymicrogyria (Barkovich Group III)}

Polymicrogyria is characterized by fused small gyri separated by shallow sulci, with cortical thickness varying from thin to thick, and can be unilateral or bilateral, often with perisylvian predominance. $^{29} 3 \mathrm{D} \mathrm{T}_{1}$-weighted sequences (MP2RAGE or MPRAGE) are essential for assessing this type of pathology $y^{30}$ because they permit clear delineation of lesion extent, which can guide surgical resection (figure 3 ). On these images, the cortex will appear hypointense and wavy at the gray and white matter interface. 3D sequences can be used to screen the whole brain for polymicrogyria, whereas $2 \mathrm{D}$ sequences with ultrahigh resolution can be an alternative when delineation of a known lesion is requested. In addition, 3D SWI, SWAN, and/or GRE $\mathrm{T}_{2}{ }^{*}$ weighted images enable visualization of small pial vessels, seen as thin hypointense lines in the malformed cortex and sulci with an arboriform distribution as an additional identifying feature; the cortex itself appears extra hyperintense in these sequences. ${ }^{6,33}$

\section{Focal Cortical Dysplasias}

Typical MRI findings of focal cortical dysplasia (FCD) include blurring of the gray-white junction with or without increased cortical thickness and cortical and subcortical signal abnormality on both $\mathrm{T}_{2}$-weighted/FLAIR and $\mathrm{T}_{1}$-weighted sequences. Detection of FCD is generally more difficult than with other types of lesions because the above-mentioned features can be subtle and inconspicuous given the complex convexities of the neocortex. Compared with 3T, lesion conspicuity and boundaries for FCD are typically better visualized at 7T (figure 4). ${ }^{34}$ 3D SWI or GRE $\mathrm{T}_{2}{ }^{*}$-weighted sequences allow visualization of intracortical signal changes (black line sign), which can improve subtyping of FCD type II..$^{10,35}$ Most centers rate $3 \mathrm{D} \mathrm{T}_{1}$-weighted and FLAIR sequences as most helpful for visualizing and diagnosing FCD because of their high image contrast at 7T; reconstructions in all 3 planes are recommended. Fluid and white matter suppression (FWMS) sequences have also been proposed to detect the transmantle sign in FCD type II. ${ }^{36}$ Detection of FCDs at $7 \mathrm{~T}$ that are completely invisible at lower field strengths seems infrequent ${ }^{5,6,8,13}$; typically, the FCD is significantly less conspicuous at $3 \mathrm{~T}$ and therefore easily missed. In other words, $7 \mathrm{~T}$ images make it easier for the human eye to detect these subtle signal changes. Occasionally, de novo appearance of new lesions at $7 \mathrm{~T}$ can be seen, although often in cases of very small lesions not optimally captured by the thicker $3 \mathrm{~T}$ slices. ${ }^{13} \mathrm{We}$ suggest scrolling carefully through slices that cover regions where a suspected FCD lesion might be located, as they might still be subtle on $7 \mathrm{~T}$ images. Finally, 7T can be helpful in ruling out FCDappearing normal cortex because of, among other factors, reduced partial volume effects compared with $3 \mathrm{~T}$ (figure 5). ${ }^{13}$

\section{Hippocampal Sclerosis}

Classic MRI features of HS are hippocampal atrophy, increased $\mathrm{T}_{2}$-weighted/FLAIR signal intensity, and loss of normal morphology. 7T MRI excels in showing hippocampal morphology, including internal structure and surface features; $2 \mathrm{D}$ coronal TSE $\mathrm{T}_{2}$-weighted and $3 \mathrm{D} \mathrm{T}_{1}$-weighted/FLAIR 

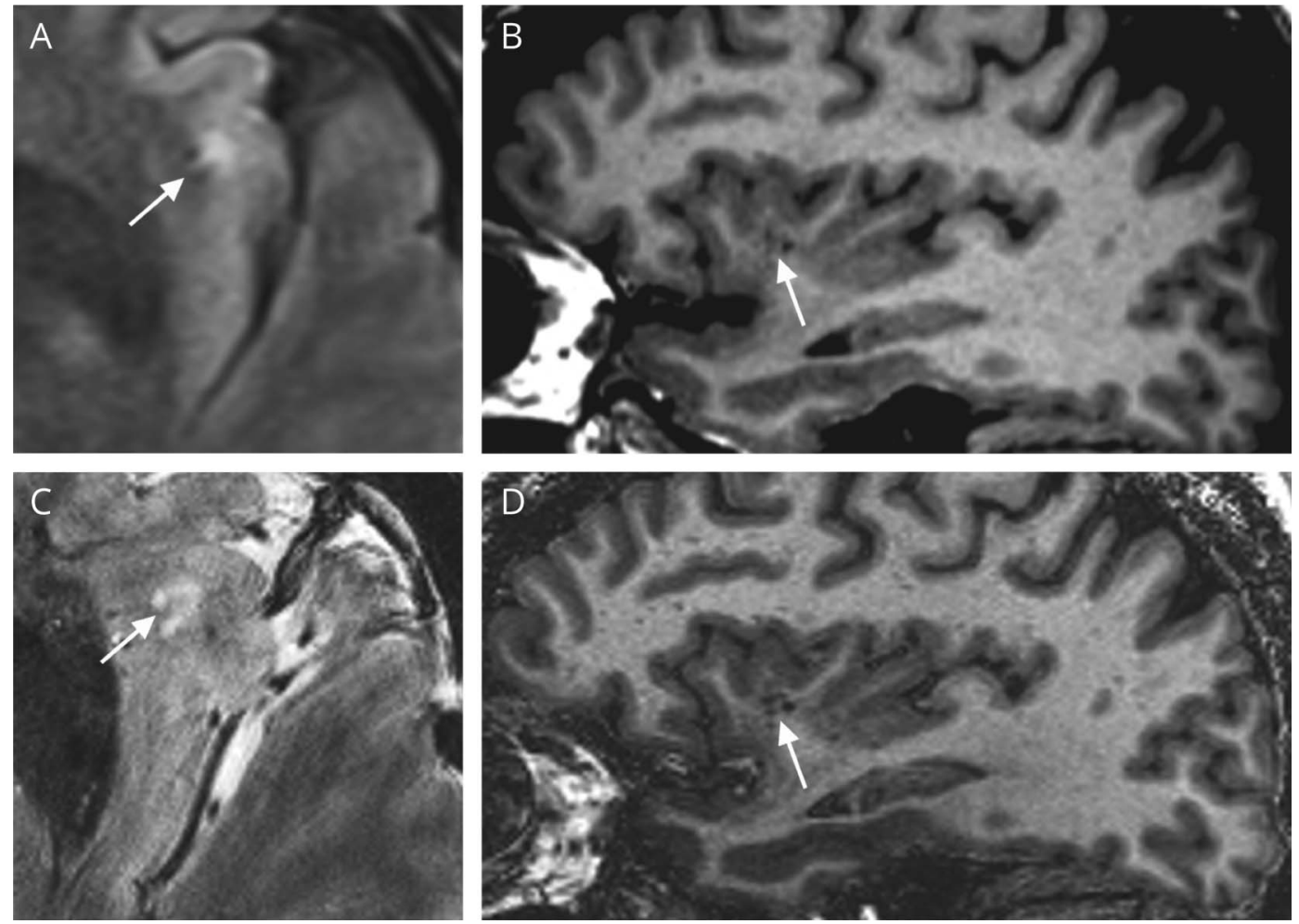

Example of a lesion suspected to be FCD at 3T but concluded to be vascular changes after reviewing 7T images. The 3T axial FLAIR (A) and 3T sagittal T ${ }_{1}$ weighted images (B) suggested subcortical FLAIR hyperintensity (arrow on A) and gray-white matter blurring (arrow on B) of the left insular cortex, suspicious for FCD. The patient had an SEEG evaluation to explore the suspected area and other possible areas for seizure generation. The suspected area in the left insula was not involved in seizure onset. $7 \mathrm{~T}_{2} \mathrm{~T}_{2}$-weighted GRE (C) and 7T sagittal $\mathrm{T}_{1}$-weighted images (D) revealed the lesion to be a vascular abnormality causing adjacent gliosis that mimicked the appearance of FCD, as indicated by arrows. Because of convincing evidence from the 7T images, the patient's surgical plan did not include the left insula.

sequences are particularly suitable for this. ${ }^{37-39}$ Hippocampal subfields can be more precisely delineated with training based on landmarks and surface features at 7T, including by automated segmentation methods. ${ }^{40-42}$ Although evident at lower field strengths, the stratum radiatum lacunosum moleculare is more consistently identified on $7 \mathrm{~T} \mathrm{~T}_{2}$-weighted images as a continuous dark band running at the internal aspect of the cornu ammonis in normal hippocampi and variably absent or indistinct in HS (figure 6). Prominent infolding can cause the dark band to appear obscured on coronal 3T images because of partial volume effects, and high-resolution images at $7 \mathrm{~T}$ help to avoid this pitfall. The absence of digitations along the hippocampal head is another sensitive and specific finding for HS that is considerably more apparent on $7 \mathrm{~T}$ images, ${ }^{43}$ as is loss of surface undulations along the inferior aspect of the hippocampal body, which is best assessed in the sagittal plane. In addition, although subclassification of HS is not currently used for presurgical assessment, pathologic examination of subfields in postoperative tissue has been shown to provide prognostic information regarding expected surgical outcomes. ${ }^{44}$ Overall, these findings suggest that preoperative detailed imaging of the entire hippocampal axis could have a significant impact on both detection and postsurgical outcome prediction.

\section{Vascular Malformations}

The most frequent findings with 7T MRI include a higher number of small vascular malformations, particularly venous malformations, and improved visualization and characterization of cavernomas. Some lesions not visible at 1.5 or $3 \mathrm{~T}$ can be observed with $7 \mathrm{~T}$, and the angioarchitecture shown with $7 \mathrm{~T}$ is close to histopathologic findings. ${ }^{45,46}$ Sequences taking advantage of the increased spatial resolution and susceptibility (SWI/ SWAN) are particularly helpful in detecting these lesions and any associated (micro) hemorrhage. SWI sequences at $7 \mathrm{~T}$ can also clearly delineate the iron-containing gliotic rim, which is important when planning sufficient surgical resection. Care must be taken, however, not to overestimate lesion size; because of the increased susceptibility effects at 7T, cavernomas and other ironcontaining structures will appear larger than they really are. ${ }^{47}$

\section{Technical Issues Relevant For Clinical Practice}

Although 7T MRI is already beneficial because of increased image contrast and spatial resolution, it is expected that its utility in epilepsy will be further expanded and optimized. Such progress, however, requires substantial engineering and 

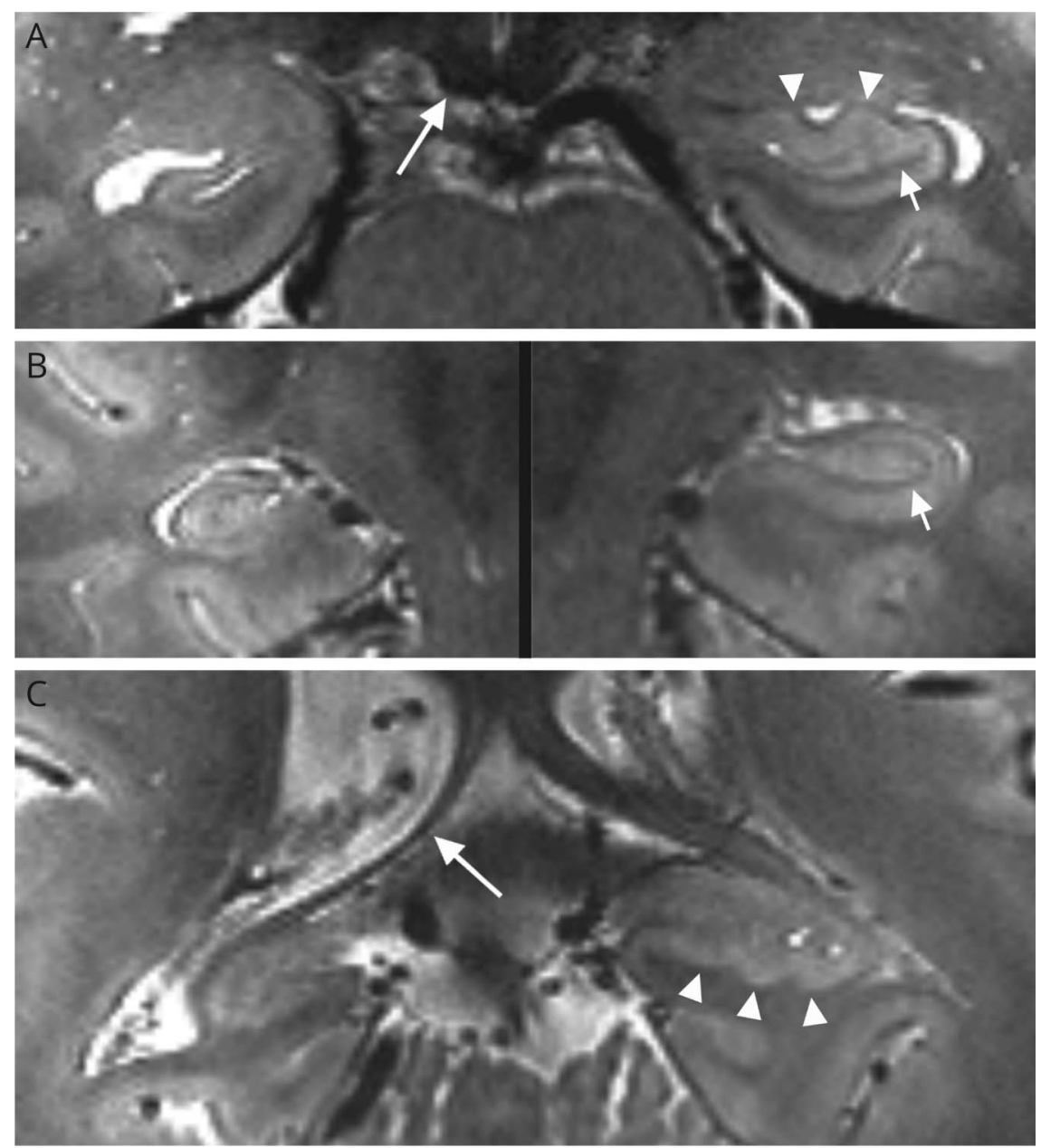

Coronal $\mathrm{T}_{2}$-weighted images at the level of the hippocampal head (A), body (B), and tail (C) show normal appearance of the left hippocampus including a continuous dark band reflecting the stratum radiatum lacunosum moleculare (arrows) and normal digitations along the head and tail (arrowheads). In contrast, the right hippocampus shows features of HS, including decreased volume, smooth outer counters, and indistinct internal architecture. Note also atrophy of the right mammillary body (long arrow in A) and fornix (long arrow in C). scientific development to account for challenges posed by working on a UHF platform. Some of these technical challenges and possible solutions will be discussed here.

\section{RF Coils, RF Shimming, and Multitransmit (pTx) Systems}

Transmit RF fields represent one of the predominant challenges at $7 \mathrm{~T}$. Higher ${ }^{1} \mathrm{H}$ Larmor frequency implies shorter RF wavelengths, translating into strong tissue contrast and signal variations. This may also lead to an increase of SAR for a given target flip angle, with a tendency to form spatially localized hot spots presenting a safety hazard. Proposed solutions can be stratified into a) existing techniques applicable to any $7 \mathrm{~T}$ platform with single/dual transmit coils; and b) techniques relying on more advanced resources, useable only in specialized research centers with pTx systems. The use of dielectric pads, described in Use of dielectric pads, perfectly illustrates an existing technique for portable RF shimming. Other existing solutions include specialized sequence designs, for example, adiabatic pulses that are relatively insensitive to RF field variations. ${ }^{48,49}$ Among advanced solutions, strategies that use expensive amplifiers and multitransmit coils are, for example, higher-order shimming and calibration-less Universal Pulse models for $\mathrm{pTx}^{50}$ The use of the latter methods in clinical settings is pending CE/FDA approval of $\mathrm{pTx} 7 \mathrm{~T}$ systems.

\section{Motion Correction}

As described in Acquisition protocol and recommended setup, the high-resolution 7T MRI sequences are particularly sensitive to motion. ${ }^{51}$ Even small movements or breathing will create artifacts in susceptibility sensitive techniques such as $\mathrm{T}_{2}{ }^{*}$-weighted sequences or echo planar imaging (EPI). ${ }^{52}$ Several retrospective and prospective correction methods have been suggested, and although promising, tracking of optical markers ${ }^{53}$ or NMR-active probes ${ }^{54}$ can be challenging because of the tight space in standard head coils and require a workflow impractical for clinical use. Alternatively, methods based on embedding fat-selective navigators ${ }^{55}$ or phase navigators ${ }^{56}$ into sequence designs have been successfully used in a variety of applications. To correct for $\mathrm{B}_{0}$ variation induced by motion, a prospective correction technique that 
dynamically updates shimming parameters in addition to the imaging geometry will be necessary. ${ }^{57}$

\section{Susceptibility Effects and Artifacts}

Different tissue types cause variations in susceptibility contrast and local field inhomogeneity. Because this property scales with field strength, tissue components exhibiting increased susceptibility - such as deoxyhemoglobin, ferritin, and hemosiderin — can be more readily visualized by $7 \mathrm{~T} \mathrm{~T}_{2}{ }^{*}$ weighted sequences (including SWI, quantitative susceptibility mapping, and BOLD imaging). ${ }^{58}$ However, tissues with different susceptibility characteristics can also cause undesirable local inhomogeneity. To minimize these undesired effects at $7 \mathrm{~T}$, advanced methods for $\mathrm{B}_{0}$ shimming (including higherorder shims) are needed. As a result, on the majority of new $7 \mathrm{~T}$ platforms, additional automated $\mathrm{B}_{0}$ shimming techniques are used; however, novel methods continue to be developed.

\section{Future Directions and Concluding Remarks}

The increased SNR and susceptibility effects at 7T not only improve spatial resolution and image contrast but also facilitate more detailed analysis of functional and molecular aspects of tissues. Several MRI techniques that particularly benefit from these advantages, and have the potential to affect epilepsy MRI, are described below.

\section{Functional MRI}

Functional connectivity studies using 7T fMRI have been conducted to assess network alterations, for example, by probing the fine-grained function and microstructure of hippocampal subfields in patients with temporal lobe epilepsy (TLE). Significantly different patterns of functional network asymmetry in the hippocampus and its subfield CA1 have been found between patients with TLE with and without HS using resting-state fMRI, possibly improving preoperative lesion localization. ${ }^{40}$ In addition, task-related fMRI mapping, which is often used for presurgical planning, benefits from the increased sensitivity to the BOLD effect, improved localization, and decreased acquisition time at $7 \mathrm{~T}$ compared with $3 \mathrm{~T}^{12}$ Simultaneous EEG/fMRI recordings ${ }^{59}$ and laminar $\mathrm{fMRI}$ using $\mathrm{UHF}^{60}$ could also improve the delineation of (intra)cortical hemodynamic correlates of epileptic activity and laminar-specific brain rhythm alterations.

\section{MR Spectroscopy (MRS) and GluCEST}

Molecular imaging at $7 \mathrm{~T}$ takes advantage of not only the increased spatial resolution but also the increased spectral resolution of UHF. Both improve sensitivity and specificity of MRS by enabling detection of molecules that are difficult to resolve at lower field strengths, including neurotransmitters such as GABA and glutamate. Previous studies have shown that an abnormal metabolism in the surgical resection region was related to the outcome after surgery, ${ }^{61}$ and although MRS could not demonstrate that metabolic characteristics can consistently lateralize the epileptogenic hippocampus, glutamine concentrations were found to correlate with verbal memory performance in patients with TLE. ${ }^{62}$ Exploring the concept of neurotransmitter brain networks using 7T MRS, another study investigated interregional GABA and glutamate associations and found that MRI-negative patients displayed an increased number of glutamate and GABA connections and increased average strength of the GABA network. ${ }^{63}$ As a whole-brain alternative to MRS, CEST primed to glutamate (GluCEST) has also been used in epilepsy. One study identified increases in the glutamate concentration in the ipsilateral hippocampus in a small case series of patients with MRI-negative TLE. ${ }^{64}$

\section{X-Nuclei MRI}

Increased sensitivity of UHF is particularly valuable for nuclei with lower abundance and SNR compared with ${ }^{1} \mathrm{H}$-protons. X-nuclei MRI could provide new insights into molecular and cellular dysfunctions beyond the visible lesions. For instance, sodium $\left({ }^{23} \mathrm{Na}\right)$ MRI, with which ionic homeostasis and cell viability can be assessed in the human brain, would be a good candidate for epilepsy imaging; a previous study has shown that ${ }^{23} \mathrm{Na}$ MRI is sensitive to pathologic processes related to epileptic activity. ${ }^{65}$

\section{Concluding Remarks}

In this article, we have presented recommendations on how to set up and evaluate a 7T MRI epilepsy protocol, based on both literature and cumulative experience of the 7T Epilepsy Task Force in clinical practice and research. There are still significant technical challenges to be solved, and the field could profit from more clinical studies comparing specifically optimized (instead of clinically used) 3T protocols with 7T sequences. Nevertheless, comparative studies of epileptogenic lesions between 7T and lower fields have shown better lesion conspicuity and delineation as well as less ambiguous findings at a higher field in a clinical setting. ${ }^{66,67}$ Thus, several clinical indications clearly exist for patients with epilepsy in whom a lesion is suspected and not convincingly seen at $3 \mathrm{~T}$ or requires better characterization. Promising future directions of $7 \mathrm{~T}$ MRI in epilepsy also include MR techniques beyond structural imaging although such novel functional and molecular methods need further clinical validation. At a time when approval for use of 7T MRI for diagnostic purposes is becoming a reality on a global level, we hope that this article provided useful guidance when setting up a 7T MRI epilepsy protocol in the clinic.

\section{Study Funding}

No targeted funding reported.

\section{Disclosures}

S. Jones receives travel and speaker fees from SIEMENS Healthineers. All other authors report no disclosures relevant to the manuscript. Go to Neurology.org/N for full disclosures.

\section{Publication History}

Received by Neurology June 2, 2020. Accepted in final form October 29, 2020. 
Appendix Authors

\begin{tabular}{|c|c|c|}
\hline Name & Location & Contribution \\
\hline $\begin{array}{l}\text { Giske } \\
\text { Opheim, MSc }\end{array}$ & $\begin{array}{l}\text { Neurobiology Research } \\
\text { Unit, Department of } \\
\text { Neurology, Rigshospitalet } \\
\text { Copenhagen University } \\
\text { Hospital, Copenhagen, } \\
\text { Denmark }\end{array}$ & $\begin{array}{l}\text { Drafting/revision of the } \\
\text { manuscript for content, } \\
\text { including medical } \\
\text { writing for content; } \\
\text { major role in the } \\
\text { acquisition of data; } \\
\text { study concept or design; } \\
\text { and analysis or } \\
\text { interpretation of data }\end{array}$ \\
\hline $\begin{array}{l}\text { Anja van der } \\
\text { Kolk, MD, PhD }\end{array}$ & $\begin{array}{l}\text { Department of Radiology, } \\
\text { University Medical Center } \\
\text { Utrecht, Utrecht University, } \\
\text { Utrecht, the Netherlands; } \\
\text { Department of Radiology, } \\
\text { Netherlands Cancer } \\
\text { Institute-Antoni van } \\
\text { Leeuwenhoek Hospital, } \\
\text { Amsterdam, the } \\
\text { Netherlands }\end{array}$ & $\begin{array}{l}\text { Drafting/revision of the } \\
\text { manuscript for content, } \\
\text { including medical } \\
\text { writing for content; } \\
\text { major role in the } \\
\text { acquisition of data; } \\
\text { study concept or design; } \\
\text { and analysis or } \\
\text { interpretation of data }\end{array}$ \\
\hline $\begin{array}{l}\text { Karin } \\
\text { Markenroth } \\
\text { Bloch, PhD }\end{array}$ & $\begin{array}{l}\text { Lund University Bioimaging } \\
\text { Center, Lund University, } \\
\text { Sweden }\end{array}$ & $\begin{array}{l}\text { Drafting/revision of the } \\
\text { manuscript for content, } \\
\text { including medical } \\
\text { writing for content; } \\
\text { major role in the } \\
\text { acquisition of data; and } \\
\text { study concept or design }\end{array}$ \\
\hline
\end{tabular}

\begin{tabular}{|c|c|c|}
\hline $\begin{array}{l}\text { Albert J. } \\
\text { Colon, MD, } \\
\text { PhD }\end{array}$ & $\begin{array}{l}\text { Department of Neurology, } \\
\text { Neurophysiology and } \\
\text { Neurosurgery, ACE } \\
\text { Kempenhaeghe/MUMC, } \\
\text { Heeze/Maastricht, the } \\
\text { Netherlands }\end{array}$ & $\begin{array}{l}\text { Drafting/revision of } \\
\text { the manuscript for } \\
\text { content, including } \\
\text { medical writing for } \\
\text { content; major role in } \\
\text { the acquisition of data; } \\
\text { and study concept or } \\
\text { design }\end{array}$ \\
\hline
\end{tabular}

Kathryn A. Hospital of the University of Drafting/revision of the Davis, MD, MS Pennsylvania, Penn manuscript for content, Epilepsy Center, including medical Philadelphia writing for content; major role in the acquisition of data; and study concept or design

\begin{tabular}{|c|c|c|}
\hline $\begin{array}{l}\text { Thomas R. } \\
\text { Henry, MD }\end{array}$ & $\begin{array}{l}\text { Division of Epilepsy, } \\
\text { Department of Neurology, } \\
\text { University of Minnesota, } \\
\text { Minneapolis }\end{array}$ & $\begin{array}{l}\text { Drafting/revision of } \\
\text { the manuscript for } \\
\text { content, including } \\
\text { medical writing for } \\
\text { content; major role in } \\
\text { the acquisition of data; } \\
\text { and study concept or } \\
\text { design }\end{array}$ \\
\hline
\end{tabular}

Jacobus F.A. Department of Radiology and Drafting/revision of the
Jansen, PhD Nuclear Medicine, Maastricht manuscript for content, University Medical Center, Maastricht, the Netherlands; $\quad$ writing for content: School for Mental Health and major role in the Neuroscience, Maastricht acquisition of data; and University, Maastricht, the study concept or design Netherlands; Department of Electrical Engineering, Eindhoven University of Technology, Eindhoven, the Netherlands

\begin{tabular}{lll}
\hline Stephen E. & Imaging Institute, Cleveland & Drafting/revision of \\
Jones, MD, & Clinic, OH & content, including \\
PhD & & medical writing for \\
& content; major role in \\
& the acquisition of data; \\
& and study concept or \\
& design \\
\hline
\end{tabular}

Appendix (continued)

\begin{tabular}{lll}
\hline Name & Location & Contribution \\
\hline $\begin{array}{l}\text { Jullie W. Pan, } \\
\text { PhD }\end{array}$ & $\begin{array}{l}\text { Department of Neurology } \\
\text { and Radiology, University of } \\
\text { Pittsburgh, PA }\end{array}$ & $\begin{array}{l}\text { Drafting/revision of the } \\
\text { manuscript for content, } \\
\text { including medical } \\
\text { writing for content; } \\
\text { major role in the } \\
\text { acquisition of data; and } \\
\text { study concept or design }\end{array}$ \\
& &
\end{tabular}

Karl Rössler, Department of Drafting/revision of the

MD, DMSc Neurosurgery, Medical manuscript for content,
University of Vienna, Austria including medical

writing for content, and major role in the acquisition of data

\begin{tabular}{ll}
\hline Joel M. Stein, & Department of Radiology, \\
MD, PhD & Hospital of the University of \\
& Pennsylvania, Philadelphia
\end{tabular}

Drafting/revision of the manuscript for content, including medical writing for content; major role in the acquisition of data; and study concept or design

\begin{tabular}{lll}
\hline $\begin{array}{l}\text { Maria } \\
\text { Compagno }\end{array}$ & $\begin{array}{l}\text { Clinical Sciences Lund, } \\
\text { Strandberg, }\end{array}$ & $\begin{array}{l}\text { Drafting/revision of the } \\
\text { MD, PhD }\end{array}$ \\
& & $\begin{array}{l}\text { manuscript for content, } \\
\text { including medical } \\
\text { writing for content, and } \\
\text { major role in the } \\
\text { acquisition of data }\end{array}$ \\
\end{tabular}

Siegfried High Field MR Center, Drafting/revision of the

Trattnig, MD, Department of Biomedical manuscript for content,
DMSC Imaging and Image Guided Therapy, Medical University of Vienna, Austria

including medical writing for content; major role in the acquisition of data; and study concept or design

\begin{tabular}{ll}
\hline Pierre- & Center for Magnetic \\
Francois Van & Resonance Research, \\
de Moortele, & University of Minnesota, \\
PhD & Minneapolis
\end{tabular}

Drafting/revision of the manuscript for content, including medical writing for content; major role in the acquisition of data; and study concept or design

\begin{tabular}{|c|c|c|}
\hline $\begin{array}{l}\text { Maria Isabel } \\
\text { Vargas, MD }\end{array}$ & $\begin{array}{l}\text { Neuroradiology Division, } \\
\text { Diagnostic Unit, University } \\
\text { Hospitals and Faculty of } \\
\text { Medicine of Geneva, } \\
\text { Switzerland }\end{array}$ & $\begin{array}{l}\text { Drafting/revision of } \\
\text { the manuscript for } \\
\text { content, including } \\
\text { medical writing for } \\
\text { content; major role in } \\
\text { the acquisition of } \\
\text { data; and study } \\
\text { concept or design }\end{array}$ \\
\hline $\begin{array}{l}\text { Irene Wang, } \\
\text { PhD }\end{array}$ & $\begin{array}{l}\text { Epilepsy Center, Cleveland } \\
\text { Clinic, OH }\end{array}$ & $\begin{array}{l}\text { Drafting/revision of the } \\
\text { manuscript for content, } \\
\text { including medical } \\
\text { writing for content; } \\
\text { major role in the } \\
\text { acquisition of data; and } \\
\text { study concept or design }\end{array}$ \\
\hline $\begin{array}{l}\text { Fabrice } \\
\text { Bartolomei, } \\
\text { MD, PhD }\end{array}$ & $\begin{array}{l}\text { Epileptology Department, } \\
\text { Institut de Neurosciences des } \\
\text { Systèmes, INSERM, Timone } \\
\text { Hospital, Aix Marseille } \\
\text { University, APHM, France }\end{array}$ & $\begin{array}{l}\text { Drafting/revision of the } \\
\text { manuscript for content, } \\
\text { including medical } \\
\text { writing for content, and } \\
\text { major role in the } \\
\text { acquisition of data }\end{array}$ \\
\hline $\begin{array}{l}\text { Neda } \\
\text { Bernasconi, } \\
\text { MD, PhD }\end{array}$ & $\begin{array}{l}\text { Neuroimaging of Epilepsy } \\
\text { Laboratory (NOEL), } \\
\text { Montreal Neurological } \\
\text { Institute and McConnell } \\
\text { Brain Imaging Centre, } \\
\text { McGill University, Canada }\end{array}$ & $\begin{array}{l}\text { Drafting/revision of the } \\
\text { manuscript for content, } \\
\text { including medical } \\
\text { writing for content }\end{array}$ \\
\hline
\end{tabular}


Appendix (continued)

\begin{tabular}{|c|c|c|}
\hline Name & Location & Contribution \\
\hline $\begin{array}{l}\text { Andrea } \\
\text { Bernasconi, } \\
\text { MD }\end{array}$ & $\begin{array}{l}\text { Neuroimaging of Epilepsy } \\
\text { Laboratory (NOEL), Montreal } \\
\text { Neurological Institute and } \\
\text { McConnell Brain Imaging } \\
\text { Centre, McGill University, } \\
\text { Canada }\end{array}$ & $\begin{array}{l}\text { Drafting/revision of the } \\
\text { manuscript for content, } \\
\text { including medical } \\
\text { writing for content }\end{array}$ \\
\hline $\begin{array}{l}\text { Boris } \\
\text { Bernhardt, } \\
\text { PhD }\end{array}$ & $\begin{array}{l}\text { Montreal Neurological } \\
\text { Institute, McGill University, } \\
\text { Canada }\end{array}$ & $\begin{array}{l}\text { Drafting/revision of the } \\
\text { manuscript for content, } \\
\text { including medical } \\
\text { writing for content }\end{array}$ \\
\hline $\begin{array}{l}\text { Isabella } \\
\text { Björkman- } \\
\text { Burtscher, } \\
\text { MD, PhD }\end{array}$ & $\begin{array}{l}\text { Department of Radiology, } \\
\text { Institute of Clinical Sciences, } \\
\text { Sahlgrenska Academy, } \\
\text { University of Gothenburg, } \\
\text { Gothenburg, Sweden }\end{array}$ & $\begin{array}{l}\text { Drafting/revision of the } \\
\text { manuscript for content, } \\
\text { including medical } \\
\text { writing for content; } \\
\text { major role in the } \\
\text { acquisition of data; and } \\
\text { study concept or design }\end{array}$ \\
\hline $\begin{array}{l}\text { Mirco } \\
\text { Cosottini, MD, } \\
\text { PhD }\end{array}$ & $\begin{array}{l}\text { Department of Translational } \\
\text { Research and New } \\
\text { Technologies in Medicine and } \\
\text { Surgery, University of Pisa, } \\
\text { Italy }\end{array}$ & $\begin{array}{l}\text { Drafting/revision of the } \\
\text { manuscript for content, } \\
\text { including medical writing } \\
\text { for content; major role in } \\
\text { the acquisition of data; } \\
\text { and study concept or } \\
\text { design }\end{array}$ \\
\hline
\end{tabular}

Sandhitsu R. Department of Neurology,

Das, PhD University of Pennsylvania, Philadelphia

Drafting/revision of the manuscript for content, including medical writing for content, and major role in the acquisition of data

\begin{tabular}{lll}
\hline Lucie Hertz- & NeuroSpin, Paris-Saclay & Drafting/revision of \\
Pannier, MD, & University, CEA, Gif-sur- & the manuscript for \\
PhD & Yvette, France; UMR 1141, & content, including \\
& University of Paris, France & medical writing for \\
& & content; major role in \\
& the acquisition of data; \\
& and study concept or \\
& design
\end{tabular}

Sara Inati, MD EEG Section, NINDS, NIH, Bethesda, MD, USA

Drafting/revision of the manuscript for content, including medical writing for content, and major role in the acquisition of data

Michael T. Department of Medica Drafting/revision of the Jurkiewicz, Imaging Children's Hospital MD, PhD at London Health Sciences Centre, Canada

manuscript for content, including medical writing for content; major role in the acquisition of data; and study concept or design

\begin{tabular}{|c|c|c|}
\hline $\begin{array}{l}\text { Ali R. Khan, } \\
\text { PhD }\end{array}$ & $\begin{array}{l}\text { Department of Medical } \\
\text { Biophysics, Schulich } \\
\text { School of Medicine and } \\
\text { Dentistry, The University } \\
\text { of Western Ontario, } \\
\text { London, Canada; Imaging } \\
\text { Research Laboratories, } \\
\text { Robarts Research } \\
\text { Institute, London, Canada }\end{array}$ & $\begin{array}{l}\text { Drafting/revision of the } \\
\text { manuscript for content, } \\
\text { including medical } \\
\text { writing for content; } \\
\text { major role in the } \\
\text { acquisition of data; and } \\
\text { study concept or design }\end{array}$ \\
\hline $\begin{array}{l}\text { Shuli Liang, } \\
\text { MD, PhD }\end{array}$ & $\begin{array}{l}\text { Functional Neurosurgery } \\
\text { Department, Beijing } \\
\text { Children's Hospital of } \\
\text { Capital Medical University, } \\
\text { Beijing, China }\end{array}$ & $\begin{array}{l}\text { Drafting/revision of the } \\
\text { manuscript for content, } \\
\text { including medical writing } \\
\text { for content; major role in } \\
\text { the acquisition of data; } \\
\text { and study concept or } \\
\text { design }\end{array}$ \\
\hline
\end{tabular}

Appendix (continued)

\begin{tabular}{|c|c|c|}
\hline Name & Location & Contribution \\
\hline $\begin{array}{l}\text { Ruoyun Ma, } \\
\text { PhD }\end{array}$ & $\begin{array}{l}\text { Center for Magnetic } \\
\text { Resonance Research, } \\
\text { University of Minnesota, } \\
\text { Minneapolis }\end{array}$ & $\begin{array}{l}\text { Drafting/revision of } \\
\text { the manuscript for } \\
\text { content, including } \\
\text { medical writing for } \\
\text { content; major role in } \\
\text { the acquisition of data; } \\
\text { and study concept or } \\
\text { design }\end{array}$ \\
\hline $\begin{array}{l}\text { Srinivasan } \\
\text { Mukundan, } \\
\text { MD, PhD }\end{array}$ & $\begin{array}{l}\text { Department of Radiology, } \\
\text { Brigham and Women's } \\
\text { Hospital, Harvard Medical } \\
\text { School, Boston, MA }\end{array}$ & $\begin{array}{l}\text { Drafting/revision of } \\
\text { the manuscript for } \\
\text { content, including } \\
\text { medical writing for } \\
\text { content, and major } \\
\text { role in the acquisition } \\
\text { of data }\end{array}$ \\
\hline
\end{tabular}

Heath Pardoe, NYU Grossman School of
PhD

Drafting/revision of the manuscript for content, including medical writing for content; major role in the acquisition of data and study concept or design

\begin{tabular}{lll}
\hline $\begin{array}{l}\text { Lars H. } \\
\text { Pinborg, MD, } \\
\text { DMSc }\end{array}$ & $\begin{array}{l}\text { Neurobiology Research } \\
\text { Unit, Department of } \\
\text { Neurology, Rigshospitalet } \\
\text { Copenhagen University } \\
\text { Hospital, Denmark; Epilepsy } \\
\text { Clinic, Department of } \\
\text { Neurology, Rigshospitalet } \\
\text { Copenhagen University } \\
\text { Hospital, Denmark }\end{array}$ & $\begin{array}{l}\text { Drafting/revision of the } \\
\text { manuscript for content, } \\
\text { including medical } \\
\text { writing for content; } \\
\text { major role in the } \\
\text { acquisition of data; and } \\
\text { study concept or design }\end{array}$ \\
\hline $\begin{array}{l}\text { Jonathan R. } \\
\text { Polimeni, PhD }\end{array}$ & $\begin{array}{l}\text { Harvard-MIT Division of } \\
\text { Health Sciences and }\end{array}$ & $\begin{array}{l}\text { Drafting/revision of the } \\
\text { manuscript for content, } \\
\text { including medical }\end{array}$ \\
& $\begin{array}{l}\text { Technology, Massachusetts } \\
\text { Institute of Technology, } \\
\text { Cambritge; Athinoula A. }\end{array}$ & writing for content \\
& $\begin{array}{l}\text { Martinos Center for } \\
\text { Biomedical Imaging, } \\
\text { Department of Radiology, } \\
\text { Harvard Medical School, } \\
\text { Massachusetts General } \\
\text { Hospital, Charlestown, MA }\end{array}$ & \\
\hline
\end{tabular}

Jean-Philippe Aix Marseille Univ, CNRS,

Ranjeva, MD, CRMBM, Marseille, France

PhD APHM, CEMEREM, Timone Hospital, Marseille, France

Drafting/revision of the manuscript for content including medical writing for content, and major role in the acquisition of data

\begin{tabular}{lll}
\hline $\begin{array}{l}\text { Esther } \\
\text { Steijvers, BSc }\end{array}$ & $\begin{array}{l}\text { Scannexus Ultrahigh Field } \\
\text { MRI Research Center, } \\
\text { Maastricht, the Netherlands }\end{array}$ & $\begin{array}{l}\text { Drafting/revision of } \\
\text { the manuscript for } \\
\text { content, including } \\
\text { medical writing for } \\
\text { content; major role in } \\
\text { the acquisition of data; } \\
\text { and study concept or } \\
\text { design }\end{array}$ \\
& & \\
& & \\
Steven & Harvard-MIT Division of & Drafting/revision of the \\
Stufflebeam, & Health Sciences and & manuscript for content, \\
MD, PhD & Technology, & writing for content \\
& Massachusetts Institute of & \\
& Technology, Cambridge; & \\
& Athinoula A. Martinos & \\
& Center for Biomedical & \\
Imaging, Department of & \\
& Radiology, Harvard & \\
& Medical School, & \\
Massachusetts General & \\
& Hospital, Charlestown, MA
\end{tabular}


Appendix (continued)

\begin{tabular}{|c|c|}
\hline Name & Location \\
\hline $\begin{array}{l}\text { Tim Jeroen } \\
\text { Veersema, MD }\end{array}$ & $\begin{array}{l}\text { Department of Neurology and } \\
\text { Neurosurgery, UMC Utrecht } \\
\text { Brain Center, University } \\
\text { Medical Center Utrecht, } \\
\text { Utrecht, the Netherlands; } \\
\text { Department of Radiology and } \\
\text { Nuclear Medicine, Meander } \\
\text { Medical Center, Amersfoort, } \\
\text { the Netherlands }\end{array}$ \\
\hline
\end{tabular}

Contribution

Drafting/revision of the manuscript for content, including medical writing for content: major role in the acquisition of data; and study concept or design

\begin{tabular}{ll}
\hline Alexandre & NeuroSpin, Paris-Saclay \\
Vignaud, MD, & University, CEA, CNRS, \\
PhD & BAOBAB, Gif-sur-Yvette, \\
& France
\end{tabular}

Drafting/revision of the manuscript for content, including medical writing for content, and major role in the acquisition of data

\begin{tabular}{ll}
\hline Natalie Voets, & Wellcome Centre for \\
PhD & Integrative Neuroimaging, \\
& FMRIB Division, Nuffield \\
& Department of Clinical \\
& Neurosciences, University \\
& of Oxford, UK
\end{tabular}

Drafting/revision of the manuscript for content, including medical writing for content, and major role in the acquisition of data

\begin{tabular}{ll}
\hline Serge & EEG and Epilepsy Unit, \\
Vulliemoz, & Neurology, Department of \\
MD, PhD & Clinical Neurosciences, \\
& University Hospitals and \\
& Faculty of Medicine of \\
& Geneva, Switzerland
\end{tabular}

Christopher J. Scannexus Ultrahigh Field

Wiggins, PhD MRI Research Center, Maastricht, the Netherlands

Drafting/revision of the manuscript for content, including medical writing for content, and major role in the acquisition of data

Drafting/revision of the manuscript for content, including medical writing for content: major role in the acquisition of data; and study concept or design

\begin{tabular}{ll}
\hline Rong Xue, PhD & State Key Lab. of Brain and \\
& Cognitive Science, Beijing \\
& MRI Center for Brain \\
& Research, Institute of \\
& Biophysics, Chinese \\
& Academy of Sciences, \\
& Beijing, China
\end{tabular}

Drafting/revision of the manuscript for content, including medical writing for content, and major role in the acquisition of data

\begin{tabular}{ll}
\hline Renzo & Neuroscience Department, \\
Guerrini, MD, & Children's Hospital A. \\
FRCP & Meyer-University of \\
& Florence and IMAGO 7 \\
& Foundation, Italy
\end{tabular}

Drafting/revision of the manuscript for content, including medical writing for content; major role in the acquisition of data; and study concept or design

Maxime Guye, Aix Marseille Univ, CNRS, MD, PhD CRMBM, Marseille, France; APHM, CEMEREM, Timone Hospital, Marseille, France

Drafting/revision of the manuscript for content, including medical writing for content; major role in the acquisition of data study concept or design; and analysis or interpretation of data

\section{References}

1. Ryvlin P, Cross JH, Rheims S. Epilepsy surgery in children and adults. Lancet Neurol 2014;13:1114-1126.

2. Téllez-Zenteno JF, Hernández Ronquillo L, Moien-Afshari F, Wiebe S. Surgical outcomes in lesional and non-lesional epilepsy: a systematic review and meta-analysis. Epilepsy Res 2010;89:310-318.

3. van der Zwaag W, Schäfer A, Marques JP, Turner R, Trampel R. Recent applications of UHF-MRI in the study of human brain function and structure: a review. NMR Biomed 2016;29:1274-1288.
4. Trattnig S, Bogner W, Gruber S, et al. Clinical applications at ultrahigh field (7 T). Where does it make the difference?. NMR Biomed 2016;29:1316-1334.

5. Feldman RE, Delman BN, Pawha PS, et al. 7T MRI in epilepsy patients with previously normal clinical MRI exams compared against healthy controls. PLoS One 2019;14:e0213642.

6. De Ciantis A, Barba C, Tassi L, et al. 7T MRI in focal epilepsy with unrevealing conventional field strength imaging. Epilepsia 2016;57:445-454

7. Colon AJ, Osch M, Buijs M, et al. MEG-guided analysis of 7T-MRI in patients with epilepsy. Seizure 2018;60:29-38.

8. Veersema TJ, Ferrier CH, van Eijsden P, et al. Seven tesla MRI improves detection of focal cortical dysplasia in patients with refractory focal epilepsy. Epilepsia Open 2017;2:162-171

9. Englot DJ, Raygor KP, Molinaro AM, et al. Factors associated with failed focal neocortical epilepsy surgery. Neurosurgery 2014;75:648-645.

10. Bartolini E, Cosottini M, Costagli M, et al. Ultra-high-field targeted imaging of focal cortical dysplasia: the intracortical black line sign in type IIb. AJNR Am J Neuroradiol 2019;40:2137-2142.

11. Rondinoni C, Magnun C, Vallota da Silva A, Heinsen HM, Amaro E Jr. Epilepsy under the scope of ultra-high field MRI. Epilepsy Behav 2019:106366.

12. Bernasconi A, Cendes F, Theodore WH, et al. Recommendations for the use of structural magnetic resonance imaging in the care of patients with epilepsy: a consensus report from the International League against Epilepsy Neuroimaging Task Force. Epilepsia 2019;60:1054-1068.

13. Wang I, Oh S, Blümcke I, et al. Value of 7T MRI and post-processing in patients with nonlesional 3T MRI undergoing epilepsy presurgical evaluation. Epilepsia 2020.

14. Beisteiner R, Robinson S, Wurnig M, et al. Clinical AMRI: evidence for a $7 \mathrm{~T}$ benefit over $3 \mathrm{~T}$. NeuroImage 2011;57:1015-1021.

15. Rauschenberg J, Nagel AM, Ladd SC, et al. Multicenter study of subjective acceptance during magnetic resonance imaging at 7 and 9.4 T. Invest Radiol 2014;49:249-259.

16. Cosottini M, Frosini D, Biagi L, et al. Short-term side-effects of brain MR examination at $7 \mathrm{~T}$ : a single-centre experience. Eur Radiol 2014;24:1923-1928.

17. Hansson B, Markenroth Bloch K, Owman T, et al. Subjectively reported effects experienced in an actively shielded 7T MRI: a large-scale study. J Magn Reson Imaging 2020;52:1265-1276.

18. Kraff O, Quick HH. 7T: physics, safety, and potential clinical applications. J Magn Reson Imaging 2017;46:1573-1589.

19. Hoff MN, McKinney At, Shellock FG, et al. Safety considerations of 7-T MRI in clinical practice. Radiology 2019;292:509-518.

20. Mugler JP III, Brookeman JR. Three-dimensional magnetization-prepared rapid gradient-echo imaging (3D MP RAGE). Magn Reson Med 1990;15:152-157.

21. Van de Moortele PF, Auerbach EJ, Olman C, Yacoub E, Uğurbil K, Moeller S. T1 weighted brain images at 7 Tesla unbiased for Proton Density, T2* contrast and RF coil receive B1 sensitivity with simultaneous vessel visualization. NeuroImage 2009 46:432-446.

22. Marques JP, Kober T, Krueger G, van der Zwaag W, Van de Moortele PF, Gruetter R. MP2RAGE, a self bias-field corrected sequence for improved segmentation and T1mapping at high field. NeuroImage 2010;49:1271-1281.

23. Visser F, Zwanenburg JJ, Hoogduin JM, Luijten PR. High-resolution magnetizationprepared 3D-FLAIR imaging at 7.0 Tesla. Magn Reson Med 2010;64:194-202.

24. Beqiri A, Hoogduin H, Sbrizzi A, Hajnal JV, Malik SJ. Whole-brain 3D FLAIR at 7T using direct signal control. Magn Reson Med 2018;80:1533-1545.

25. Pan JW, Moon CH, Hetherington HP. Cerebrospinal fluid-suppressed T(2) -weighted MR imaging at 7 T for human brain. Magn Reson Med 2019;81:2924-2936.

26. Webb AG. Dielectric materials in magnetic resonance. Concepts Magn Reson A 2011; 38A:148-184.

27. Teeuwisse WM, Brink WM, Haines KN, Webb AG. Simulations of high permittivity materials for $7 \mathrm{~T}$ neuroimaging and evaluation of a new barium titanate-based dielectric. Magn Reson Med 2012;67:912-918.

28. Feldman RE, Rutland JW, Fields MC, et al. Quantification of perivascular spaces at 7T: a potential MRI biomarker for epilepsy. Seizure 2018;54:11-18.

29. Barkovich AJ, Guerrini R, Kuzniecky RI, Jackson GD, Dobyns WB. A developmental and genetic classification for malformations of cortical development: update 2012. Brain 2012;135:1348-1369.

30. Pittau F, Baud MO, Jorge J, et al. MP2RAGE and susceptibility-weighted imaging in lesional epilepsy at 7T. J Neuroimaging 2018;28:365-369.

31. Sun K, Cui J, Wang B, et al. Magnetic resonance imaging of tuberous sclerosis complex with or without epilepsy at 7 T. Neuroradiology 2018;60:785-794.

32. Slegers RJ, Blumcke I. Low-grade developmental and epilepsy associated brain tumors: a critical update 2020. Acta Neuropathol Commun 2020;8:27.

33. De Ciantis A, Barkovich AJ, Cosottini M, et al. Ultra-high-field MR imaging in polymicrogyria and epilepsy. AJNR Am J Neuroradiol 2015;36:309-316.

34. Kelley SA, Robinson S, Crone NE, Soares BP. Bottom-of-sulcus focal cortical dysplasia presenting as epilepsia partialis continua multimodality characterization in cluding 7T MRI. Childs Nerv Syst 2018;34:1267-1269.

35. Thapaliya K, Urriola J, Barth M, Reutens DC, Bollmann S, Vegh V. 7T GRE-MRI signal compartments are sensitive to dysplastic tissue in focal epilepsy. Magn Reson Imaging 2019;61:1-8.

36. Guye M, Bartolomei F, Ranjeva JP. Malformations of cortical development: the role of 7 Tesla magnetic resonance imaging in diagnosis. Rev Neurol (Paris) 2019;175:157-162.

37. Stefanits H, Springer E, Pataraia E, et al. Seven-Tesla MRI of hippocampal sclerosis: an in vivo feasibility study with histological correlations. Invest Radiol 2017;52:666-671.

38. Gillmann C, Coras R, Rössler K, et al. Ultra-high field MRI of human hippocampi: morphological and multiparametric differentiation of hippocampal sclerosis subtypes. PLoS One 2018;13:e0196008. 
Feldman RE, Marcuse LV, Verma G, et al. Seven-tesla susceptibility-weighted analysis of hippocampal venous structures: application to magnetic-resonance-normal focal epilepsy. Epilepsia 2020;61:287-296.

40. Shah P, Bassett DS, Wisse LEM, et al. Structural and functional asymmetry of medial temporal subregions in unilateral temporal lobe epilepsy: a 7T MRI study. Hum Brain Mapp 2019;40:2390-2398.

41. Wisse LE, Kuijf HJ, Honingh AM, et al. Automated hippocampal subfield segmentation at 7T MRI. AJNR Am J Neuroradiol 2016;37:1050-1057.

42. DeKraker J, Ferko KM, Lau JC, Köhler S, Khan AR. Unfolding the hippocampus: an intrinsic coordinate system for subfield segmentations and quantitative mapping. NeuroImage 2018;167:408-418.

43. Henry TR, Chupin M, Lehéricy S, et al. Hippocampal sclerosis in temporal lobe epilepsy: findings at $7 \mathrm{~T}^{1}$. Radiology 2011;261:199-209.

44. Blümcke I, Thom M, Aronica E, et al. International consensus classification of hippocampal sclerosis in temporal lobe epilepsy: a Task Force report from the ILAE Commission on Diagnostic Methods. Epilepsia 2013;54:1315-1329.

45. Shenkar R, Venkatasubramanian PN, Zhao JC, Batjer HH, Wyrwicz AM, Awad IA Advanced magnetic resonance imaging of cerebral cavernous malformations: part I. High-field imaging of excised human lesions. Neurosurgery 2008;63:782-789.

46. Shenkar R, Venkatasubramanian PN, Wyrwicz AM, et al. Advanced magnetic resonance imaging of cerebral cavernous malformations: part II. Imaging of lesions in murine models. Neurosurgery 2008;63:790-797.

47. Campbell PG, Jabbour P, Yadla S, Awad IA. Emerging clinical imaging techniques for cerebral cavernous malformations: a systematic review. Neurosurg Focus 2010;29:E6

48. Ma R, Henry TR, Van de Moortele PF. Eliminating susceptibility induced hyperintensitie in T1w MPRAGE brain images at 7 T. Magn Reson Imaging 2019;63:274-279.

49. van Veluw SJ, Fracasso A, Visser F, et al. FLAIR images at 7 Tesla MRI highlight the ependyma and the outer layers of the cerebral cortex. NeuroImage 2015;104:100-109.

50. Deniz CM. Parallel transmission for ultrahigh field MRI. Top Magn Reson Imaging 2019;28:159-171.

51. Ladd ME, Bachert P, Meyerspeer M, et al. Pros and cons of ultra-high-field MRI/MRS for human application. Prog Nucl Magn Reson Spectrosc 2018;109:1-50.

52. van Gelderen P, de Zwart JA, Starewicz P, Hinks RS, Duyn JH. Real-time shimming to compensate for respiration-induced B0 fluctuations. Magn Reson Med 2007;57:362-368.

53. DiGiacomo P, Maclaren J, Aksoy M, et al. A within-coil optical prospective motioncorrection system for brain imaging at 7T. Magn Reson Med 2020;84:1661-1671.
54. Aranovitch A, Haeberlin M, Gross S, et al. Prospective motion correction with NMR markers using only native sequence elements. Magn Reson Med 2018;79:2046-2056.

55. Boer VO, Andersen M, Lind A, Lee NG, Marsman A, Petersen ET. MR spectroscopy using static higher order shimming with dynamic linear terms (HOS-DLT) for improved water suppression, interleaved MRS-fMRI, and navigator-based motion correction at 7T. Magn Reson Med 2020;84:1101-1112.

56. Liu J, van Gelderen P, de Zwart JA, Duyn JH. Reducing motion sensitivity in 3D highresolution $\mathrm{T}(2)^{*}$-weighted MRI by navigator-based motion and nonlinear magnetic field correction. NeuroImage 2020;206:116332.

57. Deelchand DK, Joers JM, Auerbach EJ, Henry PG. Prospective motion and B(0) shim correction for MR spectroscopy in human brain at 7T. Magn Reson Med 2019;82:1984-1992.

58. Bian W, Hess CP, Chang SM, Nelson SJ, Lupo JM. Susceptibility-weighted MR imaging of radiation therapy-induced cerebral microbleeds in patients with glioma: a comparison between 3T and 7T. Neuroradiology 2014;56:91-96.

59. Jorge J, Grouiller F, Gruetter R, van der Zwaag W, Figueiredo P. Towards high-quality simultaneous EEG-fMRI at $7 \mathrm{~T}$ : Detection and reduction of EEG artifacts due to head motion. NeuroImage 2015;120:143-153.

60. Norris DG, Polimeni JR. Laminar (f)MRI: a short history and future prospects. NeuroImage 2019;197:643-649.

61. Pan JW, Duckrow RB, Gerrard J, et al. 7T MR spectroscopic imaging in the localization of surgical epilepsy. Epilepsia 2013;54:1668-1678.

62. Voets NL, Hodgetts CJ, Sen A, Adcock JE, Emir U. Hippocampal MRS and subfield volumetry at 7T detects dysfunction not specific to seizure focus. Sci Rep 2017;7:16138.

63. van Veenendaal TM, Backes WH, Tse DHY, et al. High field imaging of large-scale neurotransmitter networks: proof of concept and initial application to epilepsy. NeuroImage Clin 2018;19:47-55.

64. Davis KA, Nanga RP, Das S, et al. Glutamate imaging (GluCEST) lateralizes epileptic foci in nonlesional temporal lobe epilepsy. Sci Transl Med 2015;7:309ra161.

65. Ridley B, Marchi A, Wirsich J, et al. Brain sodium MRI in human epilepsy: disturbances of ionic homeostasis reflect the organization of pathological regions. NeuroImage 2017;157:173-183.

66. Obusez EC, Lowe $\mathrm{M}$, Oh SH, et al. 7T MR of intracranial pathology: preliminary observations and comparisons to $3 \mathrm{~T}$ and 1.5T. NeuroImage 2018;168:459-476.

67. Springer E, Dymerska B, Cardoso PL, et al. Comparison of routine brain imaging at 3 $\mathrm{T}$ and $7 \mathrm{~T}$. Invest Radiol 2016;51:469-482.
ค

$\underset{\text { PODCAST }}{\text { Neurology }}$

February 16, 2021

\section{Frequency of Biologically Defined Alzheimer Disease in Relation to Age, Sex, APOE \&4, and Cognitive Impairment (see p. 304)}

In the first segment, Dr. Gregg Day talks with Dr. Joseph Therriault on the frequency of biologically defined Alzheimer disease. In the second part of the podcast, Dr. Fabio Nascimento talks with Dr. Orrin Devinsky in the third of a 4-part series called Update in Epilepsy.

Disclosures can be found at Neurology.org.

CME Opportunity: Listen to this week's Neurology ${ }^{\circledR}$ Podcast and earn 0.5 AMA PRA Category $1 \mathrm{CME}$ Credits $^{\mathrm{TM}}$ by completing the online podcast quiz. 